\title{
PEMETAAN DAN SISTEM PENGELOLAAN EKOSISTEM MANGROVE UNTUK EKOWISATA DI KECAMATAN KUTA RAJA KOTA BANDA ACEH
}

Diajukan untuk Memenuhi Sebagian dari Syarat untuk Memperoleh Gelar Magister Pendidikan Biologi dalam Bidang Ilmu Pendidikan Biologi

\section{TESIS}

\author{
Oleh
}

SYIFA SAPUTRA

NIM 1109200150009

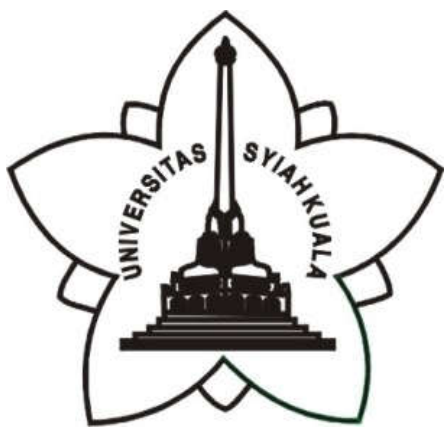

PROGRAM STUDI MAGISTER PENDIDIKAN BIOLOGI PROGRAM PASCASARJANA

UNIVERSITAS SYIAH KUALA

DARUSSALAM BANDA ACEH 


\title{
Halaman Pengesahan
}

\section{JUDUL TESIS : PEMETAAN DAN SISTEM PENGELOLAAN} EKOSISTEM MANGROVE UNTUK EKOWISATA DI KECAMATAN KUTA RAJA KOTA BANDA ACEH

\author{
Nama Mahasiswa : SYIFA SAPUTRA \\ NIM $\quad: 1109200150009$ \\ Program Studi : MAGISTER PENDIDIKAN BIOLOGI
}

\section{Menyetujui}

Komisi Pembimbing
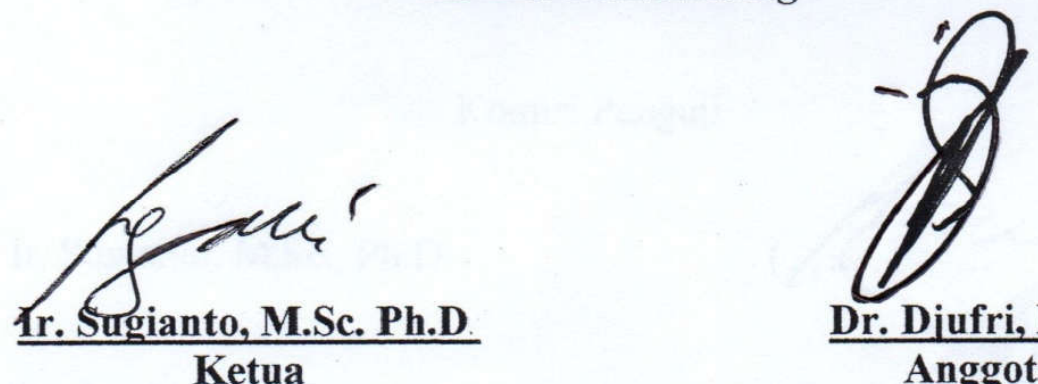

Ketua

Dr. Diufri, M.Si.

Anggota

Mengetahui,

Ketua Program Studi

Magister Rendidikan Biologi

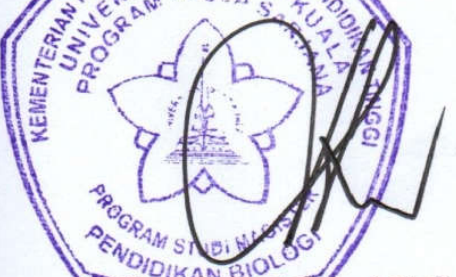

Prof. Dr.M. Ali S., M.Si

NIP. 195903251986031003
Direktur Pascasarjana

Universitas Syiah Kuala $f$

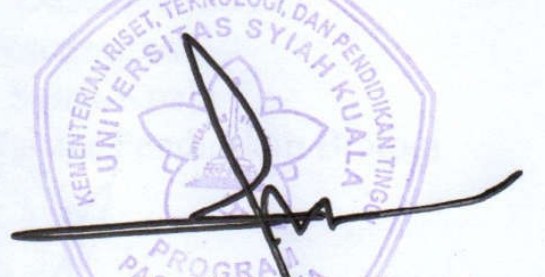

Prof. Dr Ir. Darusman, M.Sc

NIP. 196210091987021001 


\title{
Pengesahan Tim Penguji
}

\section{PEMETAAN DAN SISTEM PENGELOLAAN EKOSISTEM MANGROVE UNTUK EKOWISATA DI KECAMATAN KUTA RAJA KOTA BANDA ACEH}

\author{
Nama Mahasiswa : SYIFA SAPUTRA \\ NIM \\ : 1109200150009 \\ Program Studi \\ : MAGISTER PENDIDIKAN BIOLOGI
}

Telah dipertahankan di depan sidang penguji

Pada tanggal 10 desember 2015

Dan dinyatakan telah memenuhi syarat untuk diterima.

\section{Komisi Penguji}

1. Ir. Sugianto, M.Sc., Ph.D.

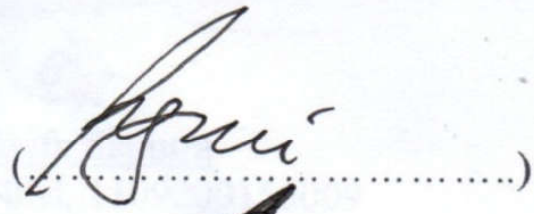

2. Dr. Djufri, M.Si.

3. Prof. Dr. M. Ali S., M.Si.

4. Dr. Said Munzir, S.Si., M.Eng.Sc.

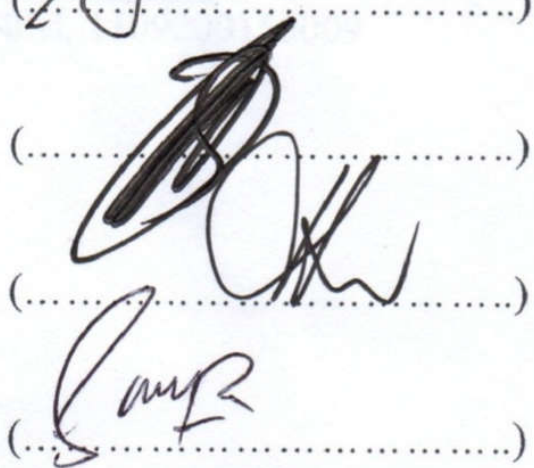

Banda Aceh, Desember 2015

Program Pascasarjana Uniyersitas Syiah Kuala

Ketua Promam Studi Magister Pendidikan Biologi

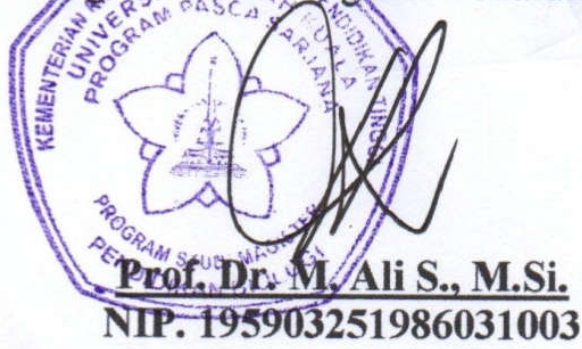




\section{PERYATAAN}

Dengan ini saya menyatakan bahwa tesis dengan judul : "Pemetaan Dan Sistem Pengelolaan Ekosistem Mangrove Untuk Ekosiwata Di Kecamatan Kuta Raja Kota Banda Aceh" Ini seluruh isinya adalah benar-benar karya saya sendiri, dan saya tidak melakukan penjiplakan atas pengutipan dengan cara-cara yang tidak sesuai dengan etika keilmuan yang berlaku dalam masyarakat keilmuan. Atas pernyatan ini, apabila ditemukan adanya pelanggaran terhadap etika keilmuan dalam karya saya ini, atau ada klaim dari pihak lain terhadap keaslian karya saya ini, maka saya besedia menerima sanksi yang berlaku pada Program Pascasarjana Universitas Syiah Kuala.

Banda Aceh, 10 Desember 2015

Yang membuat pernyataan

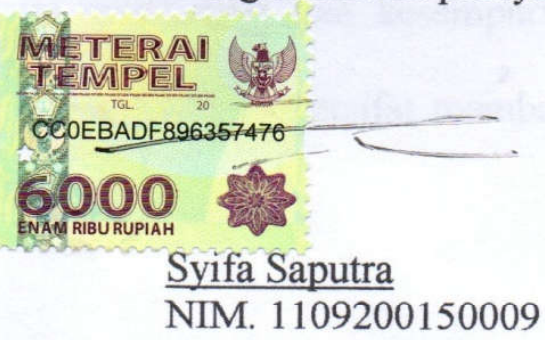




\section{KATA PENGANTAR}

Puji dan syukur penulis panjatkan kepada Allah SWT atas segala Ridha dan Rahmat-Nya sehingga penulis dapat menyelesaikan tesis. Tema yang dipilih dalam melakukan penelitian ini dengan judul "Pemetaan dan Sistem Pengelolaan Ekosistem Mangrove Untuk Ekowisata di Kecamatan Kuta Raja Kota Banda Aceh". Tesis merupakan salah satu syarat untuk memperoleh gelar Magister Pendidikan Biologi pada Program Studi Magister Pendidikan Biologi Program Pascasarjana Universitas Syiah Kuala.

Penulis menyadari bahwa tesis ini masih jauh dari kesempurnaan, oleh sebab itu penulis mengharapkan kritik dan saran yang bersifat membangun dari semua pihak demi kesempurnaan tesis ini.

Banda Aceh, 10 Desember 2015

Syifa Saputra 


\section{UCAPAN TERIMA KASIH}

Puji dan syukur penulis panjatkan kepada Allah SWT atas segala Ridha dan Rahmat-Nya sehingga penulis dapat menyelesaikan tesis. Tema yang dipilih dalam melakukan penelitian ini dengan judul "Pemetaan dan Sistem Pengelolaan Ekosistem Mangrove Untuk Ekowisata di Kecamatan Kuta Raja Kota Banda Aceh". Selesainya tesis ini tidak terlepas dari bantuan berbagai pihak, sehingga pada kesempatan ini penulis ingin menyampaikan ucapan terima kasih yang sebesar-besarnya kepada :

1. Ir. Sugianto, M.Sc., Ph.D. sebagai pembimbing utama dan Dr. Djufri, M.Si. Sebagai pembimbing pembantu yang telah banyak memberikan kritikan, saran serta arahan sehingga dapat terselesaikannya penyusunan tesis ini.

2. Prof. Dr. Ali. S., M.Si. Dan Dr. Said Munzir, S.Si., M.Eng.Sc. yang telah bersedia menjadi dosen penguji/pengkaji pada sidang tesis serta memberikan masukan untuk perbaikan tesis.

3. Direktur Program Pascasarjana Universitas Syiah Kuala beserta seluruh staf dan dosen yang telah banyak memberikan bantuan lansung maupun tidak lansung selama penulis menempuh pendidikan.

4. Ayah dan Bunda serta adik-adikku yang telah memberikan dukungan baik moril maupun materil.

5. Isteriku tercinta, Erlina Zakaria yang terus memberikan support serta motivasi untuk menyelesaikan tesis serta putra-putraku tercinta Muhammad Sulthan Almusawwa (4 tahun) dan Ahmad Giza Albiruni (9 bulan) yang telah menjadi penyemangat dalam penyelesaian tesis. 
6. Keluarga Besar Program Studi Magister Pendidikan Biologi Unsyiah dan semua pihak yang tidak dapat disebutkan satu per satu yang telah banyak memberikan bantuan, masukan dan motivasi dalam proses penulisan tesis.

Akhirnya penulis mengharapkan masukan, koreksi dan saran untuk memperkuat kelemahan dan melengkapi kekurangan tersebut.

Banda Aceh, 10 Desember 2015

Syifa Saputra 


\begin{abstract}
ABSTRAK
Syifa Saputra, Pemetaan Dan Sistem Pengelolaan Ekosistem Mangrove Untuk Ekowisata Di Kecamatan Kuta Raja Kota Banda Aceh.

Pemetaan dan sistem pengelolaan ekosistem mangrove untuk ekowisata di kecamatan Kuta Raja Kota Banda Aceh belum efektif dikarenakan jarang mendapat perhatian dari semua pihak sehingga diperlukan pemetaan dan pengelolaan ekosistem hutan mangrove melalui model empang parit dan model komplangan (silvofishery). Tujuan penelitian ini adalah untuk memetakan dan mengetahui sistem pengelolaan ekosistem mangrove untuk ekowisata dan untuk mengetahui sistem pengelolaan ekowisata di Kecamatan Kuta Raja Kota Banda Aceh. Metode dalam penelitian ini adalah deskriptif dan kualitatif. Teknik pengumpulan data melalui survey dan observasi lapangan dengan mengidentifikasikan jenis-jenis mangrove dan biota ekosistem mangrove serta observasi kegiatan model empang parit dan model komplangan. Analisis data melalui software SIG selanjutnya ditampilkan dalam bentuk peta. Hasil penelitian ditemukan ada 18 jenis mangrove sedangkan jenis biota ekosistem mangrove dibatasi pada burung 9 (Sembilan) jenis, reptile 2 (dua) Jenis, ikan 4 (empat) jenis, crustacea 4 (empat) jenis dan serangga 4 (empat) jenis serta terdapat makam rajaraja Kesultanan Aceh. Kesimpulan pemetaan dan pengelolaan ekosistem mangrove untuk ekowisata melalui partisipasi aktif masyarakat di kecamatan Kuta Raja Kota Banda Aceh menjadi tertata dengan baik dan menarik untuk ekowisata
\end{abstract}

Kata Kunci : Pemetaan, Sistem Pengelolaan, Ekosistem Mangrove dan Ekowisata. 


\begin{abstract}
Syifa Saputra, Mapping And Mangrove Ecosystem Management System For Ecotourism In the district of Kuta Raja Banda Aceh.

Mapping and mangrove ecosystem management system for eco-tourism in the district of Kuta Raja Banda Aceh have not been effective because rarely gets the attention of all parties so that the necessary mapping and management of mangrove forest ecosystems through ditches and ponds models komplangan models (Silvofishery). The purpose of this study is to map and determine the management system of mangrove ecosystem for ecotourism and to determine the management system of ecotourism in the district of Kuta Raja Banda Aceh. The method in this research is descriptive and qualitative. The technique of collecting data through surveys and field observations by identifying the types of mangrove and mangrove ecosystem biota and observation activities ditches and ponds models komplangan models. Analysis of data through GIS software will be displayed in the form of a map. The research found there were 18 types of mangrove, while biota mangrove ecosystem is limited to bird 9 (nine) types, reptiles 2 (two) type, fish 4 (four) types, crustaceans four (4) types and insects 4 (four) and there tombs of the kings of the Sultanate of Aceh. Conclusion mapping and management of mangrove ecosystem for ecotourism through the active participation of the community in the district of Kuta Raja Banda Aceh into a well-organized and attractive for ecotourism
\end{abstract}

Keywords: Mapping, Management System, and Ecotourism Mangrove Ecosystem 


\section{DAFTAR ISI}

Halaman

LEMBARAN PENGESAHAN

PERNYATAAN KEASLIAN TESIS

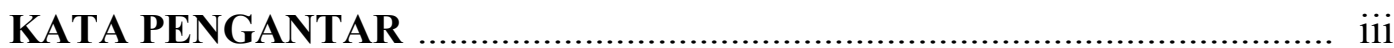

UCAPAN TERIMA KASIH …...................................................... iv

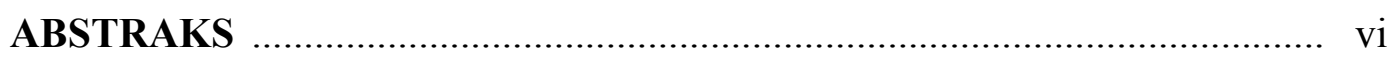

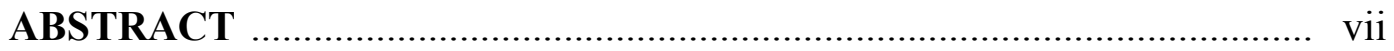

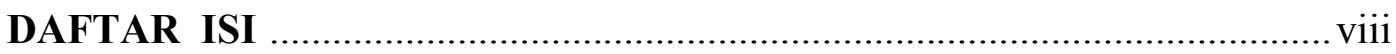

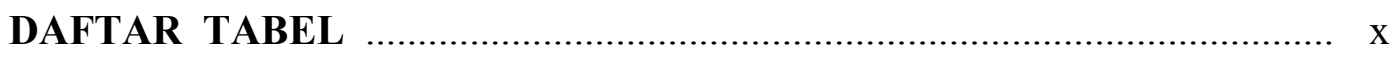

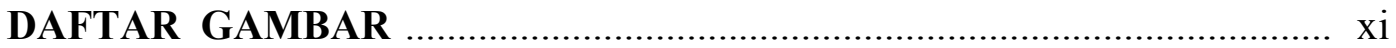

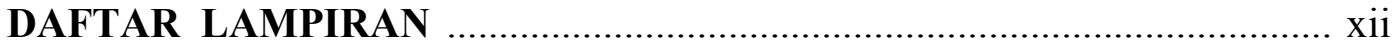

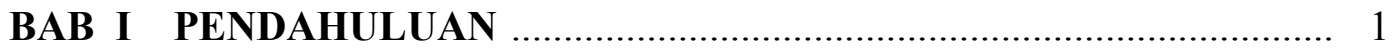

1.1. Latar Belakang ........................................................................ 1

1.2. Rumusan Masalah.......................................................... 3

1.3. Tujuan Penelitian ................................................................... 4

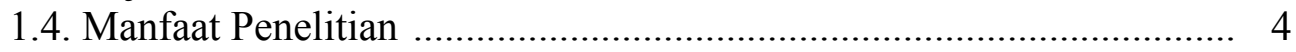

1.5. Definisi Operasional ….................................................................... 4

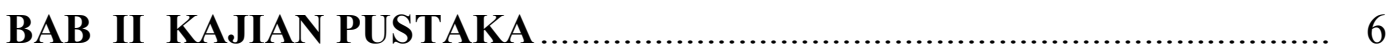

2.1. Pemetaan.......................................................................................... 6

2.2. Sistem Pengelolaan Ekosistem Mangrove …........................................ 7

2.2.1 Pengelolaan Ekosistem Mangrove............................................. 7

2.2.2 Pengertian Ekosistem Mangrove ............................................... 15

2.2.3 Karakteristik dan Fungsi Ekosistem Mangrove.......................... 16

2.2.4 Zonasi dan Penyebaran Hutan Mangrove..................................... 19

2.2.5 Jalur Hijau Hutan Mangrove .................................................... 24

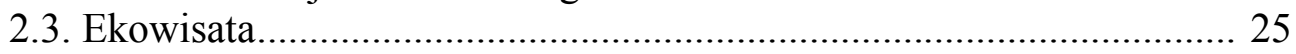

2.3.1 Ekowisata Mangrove ........................................................... 26

2.3.2 Prinsip dan Karakteristik Ekowisata........................................ 28

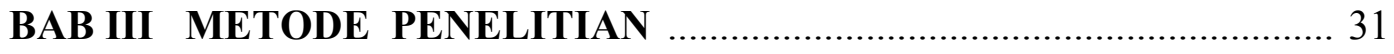

3.1. Gambaran Umum Lokasi Penelitian.................................................. 31

3.2. Tempat dan Waktu Penelitian.......................................................... 33

3.3. Alat dan Bahan Penelitian .................................................................. 33

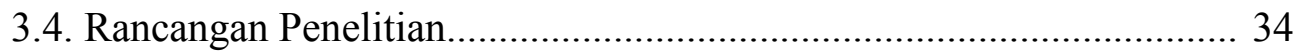

3.5. Pendekatan, Metode dan Jenis Penelitian ............................................. 35

3.6. Objek Penelitian............................................................................. 36

3.7. Parameter Penelitian ............................................................................ 36

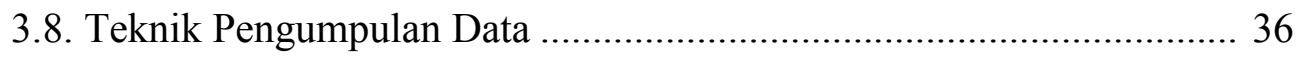

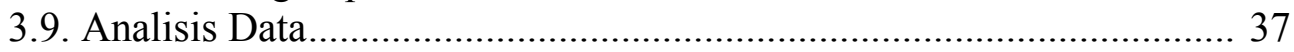

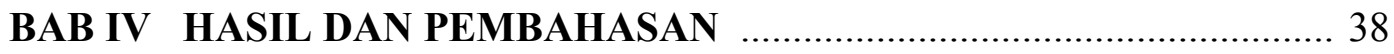

4.1. Kondisi Ekosistem Mangrove .......................................................... 38

4.1.1. Sebaran Mangrove Wilayah Penelitian ..................................... 43

viii 
4.1.2. Aspek Ekologi Ekosistem Mangrove Wilayah Penelitian.......... 44

4.1.3. Zonasi Hutan Mangrove Wilayah Penelitian.............................. 46

4.2. Jenis Biota Wilayah Penelitian ........................................................... 47

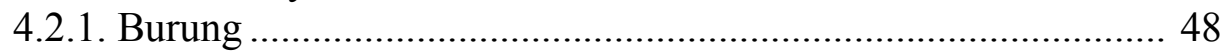

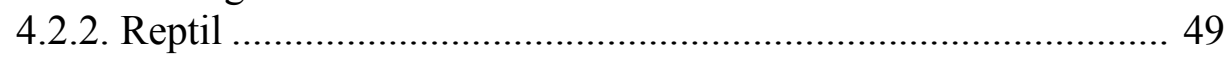

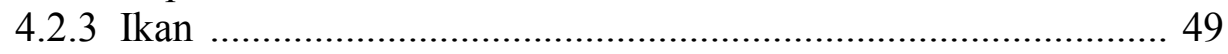

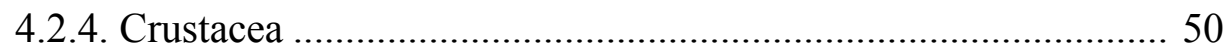

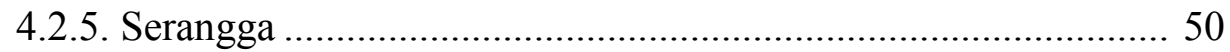

4.3. Sistem Pengelolaan Ekosistem Mangrove ......................................... 51

4.3.1. Teknik Silvofishery ............................................................... 53

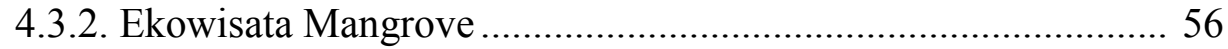

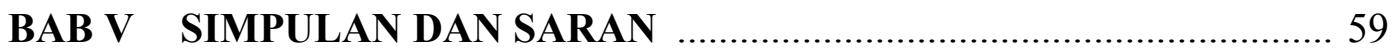

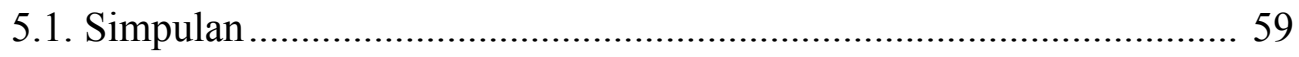

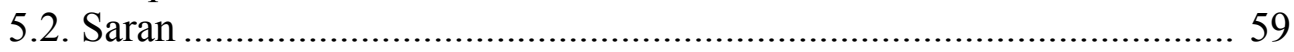

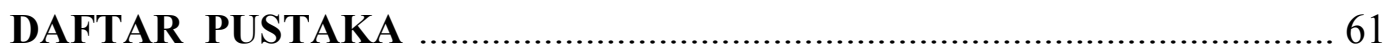

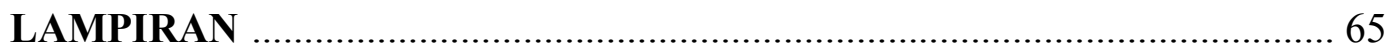

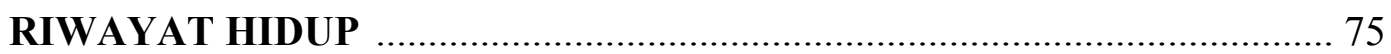




\section{DAFTAR TABEL}

Tabel

Halaman

3.1 Alat dan bahan yang digunaka dalam penelitian lapangan................... 33

4.1 Jenis mangrove sebelum tsunami dan sesudah tsunami 2015 .............. 41

4.2 Jenis mangrove ditemukan di lokasi penelitian ................................. 43

4.3 Jenis burung yang terdapat di lokasi penelitian ................................ 48

5.5 Jenis ikan yang terdapat di lokasi penelitian ................................... 50 


\section{DAFTAR GAMBAR}

Gambar

Halaman

2.1. Skema alur pendekatan secara buttom-up .................................... 14

2.2. Salah satu tipe zonasi hutan mangrove di Indonesia........................ 22

2.3. Bentuk akar tumbuhan hutan mangrove reproduktif........................ 23

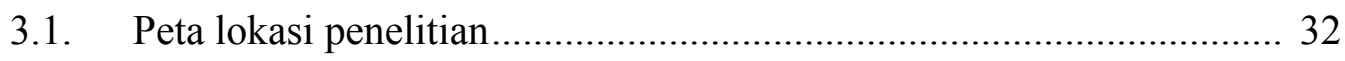

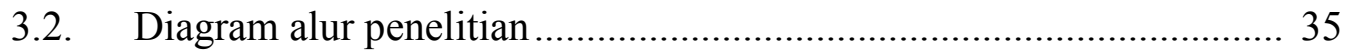

4.1. Peta sebaran mangrove tahun 2004 .............................................. 39

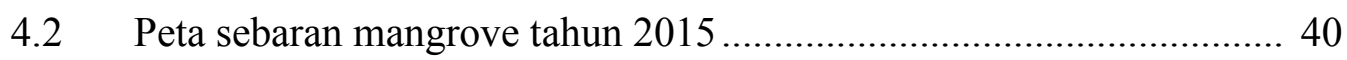

4.3. Kondisi mangrove yang terdapat di lokasi penelitian ....................... 42

4.4. Subtrat Tanah yang terdapat di lokasi penelitian .............................. 45

4.5. Zonasi hutan mangrove di lokasi penelitian.................................... 47

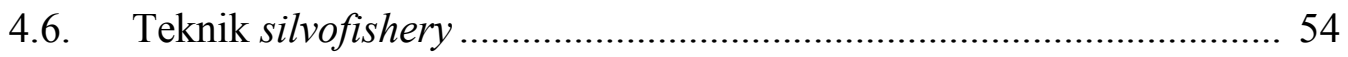

4.7. Model Teknik silvofihery di Lokasi Penelitian ................................ 55

4.8. Salah Satu wisata Mangrove di wonorejo ....................................... 57

4.9 Makam raja-raja Kesultanan Aceh di kawasan mangrove .................. 58 


\section{DAFTAR LAMPIRAN}

Lampiran

Halaman

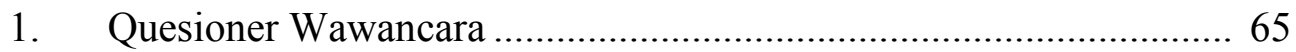

2. Jenis-jenis mangrove yang tersebar di lokasi penelitian..................67

3. Jenis burung yang terdapat di lokasi penelitian .............................. 69

4. Jenis ikan yang terdapat di lokasi penelitian................................... 71

5. Jenis Crustacea yang terdapat di lokasi penelitian.......................... 72

6. Dokumentasi Penelitian ................................................................... 73 


\section{BAB I}

\section{PENDAHULUAN}

\subsection{Latar Belakang}

Kawasan pesisir dan laut Indonesia memegang peranan penting, karena kawasan ini memiliki nilai yang strategis. Dikatakan daerah yang strategis karena hampir semua kawasan pesisir di Indonesia merupakan pintu gerbang utama aktivitas ekonomi kelautan di wilayahnya masing-masing, sementara dikatakan paling rentan terhadap perubahan yang terjadi secara alami, akibat aktivitas manusia, maupun kombinasi dari keduanya. Namun diantara faktor-faktor tersebut, pengaruh aktivitas manusia yang tidak ramah lingkungan merupakan penyebab utamanya, misalnya kerusakan terumbu karang, kerusakan mangrove, erosi pantai, maupun pencemaran.

Sistem pengelolaan ekosistem mangrove untuk ekowisata memerlukan penelitian dasar maupun terapan untuk mengeksplorasi data lingkungan dan sosial baik kondisi internal dan eksternal, yang didukung oleh semua stakeholder, baik pemerintah, swasta, LSM, penduduk lokal, perguruan tinggi serta organisasi international yang relevan. Stakeholder terutama pemerintah kabupaten/kota sebagai pengambil kebijakan harus mempunyai persepsi, sikap, perilaku yang sama dalam pengelolaan ekowisata.

Pemanfaatan ekosistem mangrove untuk ekowisata sejalan dengan pergeseran minat wisatawan dari wisatawan yang hanya datang melakukan wisata tanpa ada unsur pendidikan dan konservasi (old tourism) menjadi wisatawan yang datang untuk melakukan wisata yang ada unsur pendidikan dan konservasi 
didalamnya (new tourism), untuk mengelola dan mencari daerah tujuan ekowisata yang spesifik alami dan kaya akan keanekaragaman hayati.

Ekowisata secara konseptual merupakan konsep pengelolaan dan pengembangan serta penyelenggaraan kegiatan pariwisata yang berbasis pemanfaatan lingkungan untuk perlindungan serta berintikan partisipasi aktif masyarakat dan dengan penyajian produk bermuatan pendidikan dan pembelajaran, berdampak negatif minimum terhadap lingkungan, memberikan kontribusi positif terhadap pembangunan daerah dan diberlakukan kawasan lindung, kawasan terbuka, kawasan binaan serta kawasan budaya (Sekartjakrarini, 2004).

Kota Banda Aceh merupakan kawasan ujung barat pulau sumatera yang lansung berhadapan dengan Selat Malaka dan Samudera Hindia dan juga merupakan salah satu kota yang paling parah diterjang gelombang tsunami tahun 2004. Sebagai objek penelitian di Kota Banda Aceh adalah Kecamatan Kuta Raja dimana pada kawasan ini terdapat ekosistem mangrove yang masih alami yaitu di Gampong Jawa serta sebagian Gampong Pande, sedangkan yang lainnya penanaman kembali yang melibatkan masyarakat. Luas ekosistem mangrove di Kecamatan Kuta Raja tahun 2004 sebelum tsunami 66,25 ha dan tahun 2015 setelah tsunami 47,9 ha.

Sesuai dengan Qanun Kota Banda Aceh No. 4 Tahun 2009, tentang Rencana Tata Ruang Wilayah Kota Banda Aceh Tahun 2009-2029, dalam Arahan Pemanfaatan Ruang Kota agar diperoleh pengembangan Kegiatan Wisata di Kawasan Konservasi serta pengembangan Kawasan Wisata Alam dan Pantai, Wisata Spiritual, Wisata Bersejarah dan Wisata Tsunami. Oleh sebab itu, dalam 
Perencanaan Pola Ruang Kota untuk kawasan hutan bakau di peruntukkan lahan dengan luas 463,28 ha dengan persentase 7,55\% dan tersebar di wilayah pesisir Kota Banda Aceh.

Hutan mangrove di Kecamatan Kuta Raja selama ini pengelolaannya belum maksimal, hal ini dilihat belum meratanya penanaman mangrove. Masyarakat setempat menganggap keberadaan hutan mangrove hanya sebagai tiang penyangga dari abrasi air laut dan sebagai penahan angin laut, hanya beberapa orang dari masyarakat setempat yang paham akan manfaat mangrove.

Oleh karena itu, untuk mengoptimalkan pengelolaan sumberdaya ekosistem mangrove perlu dilakukan pemetaan untuk mengetahui kondisi ekosistem mangrove di Kuta Raja. Hasil pemetaan diharapkan dapat membantu dalam proses pengambilan keputusan terhadap sistem pengelolaan ekosistem mangrove untuk ekowisata di Kecamatan Kuta Raja Kota Banda Aceh.

\subsection{Rumusan Masalah}

Rumusan permasalahan dalam penelitian adalah sebagai berikut :

1. Apakah dapat dipetakan pengelolaan dan ekosistem mangrove untuk ekowisata di Kecamatan Kuta Raja Kota Banda Aceh?.

2. Bagaimana sistem pengelolaan ekosistem mangrove untuk ekowisata di Kecamatan Kuta Raja Kota Banda Aceh?. 


\subsection{Tujuan Penelitian}

Tujuan dalam penelitian ini adalah sebagai berikut :

1. Untuk memetakan sebaran dan ekosistem mangrove di Kecamatan Kuta Raja Kota Banda Aceh dalam bentuk peta tematik.

2. Untuk mengetahui sistem pengelolaan ekosistem mangrove untuk ekosiwata di Kecamatan Kuta Raja Kota Banda Aceh.

\subsection{Manfaat Penelitian}

Penelitian ini diharapkan dapat memberikan informasi dan kontribusi dalam merumuskan konsep sistem pengelolaan ekosistem mangrove kepada Pemerintah Kota Banda Aceh, masyarakat, dan stakeholder lainnya dapat berpartisapasi dalam pengelolaan dan mampu mengevaluasi perkembangan kegiatan ekowisata. Selain itu, penelitian ini diharapkan juga memberi manfaat pada dunia pendidikan yaitu dapat digunakan sebagai bahan ajar pada mata kuliah Pengembangan Sumberdaya Pesisir dan Laut dan Biologi Konservasi.

\subsection{Defini operasional}

1. Ekosistem Mangrove adalah suatu hubungan tempat berlangsungnya kehidupan yang mencerminkan hubungan timbal balik antara makhluk hidup dengan lingkungannya dan diantara makhluk hidup itu sendiri. Terdapat pada wilayah pesisir, pengaruh pasang surut air laut, dan didominasi oleh spesies pohon atau semak yang khas dan mampu tumbuh dalam perairan asin/payau.

2. Sistem Informasi Geografis Sistem Informasi Geografis (SIG) merupakan sistem informasi berbasis komputer yang merupakan penggabungan antara 
unsur peta (geografis) dan informasi tentang peta tersebut (data atribut), yang dirancang untuk mendapatkan, mengolah, memanipulasi, analisis, memperagakan dan menampilkan data spasial untuk menyelesaikan perencanaan, mengolah dan meneliti permasalahan.

3. Ekowisata merupakan perjalanan wisata ke suatu lingkungan yang bersifat rekreasi, pendidikan dan konservasi. Pada perjalanan wisata, wisatawan tidak sekedar dapat rekreasi ke kawasan alami yang belum terjadi kerusakan, melainkan juga dapat mempelajari, menjaga dan menikmati keberadaan alam dengan segala manifestasi di dalamnya. 


\section{BAB II}

\section{KAJIAN PUSTAKA}

\subsection{Pemetaan}

Sistem Informasi Geografis (SIG) merupakan suatu sistem teknologi informasi yang dirancang untuk bekerja dengan data yang bereferensi spasial atau berkoordinat dan juga merupakan kesatuan formal yang terdiri dari berbagai sumberdaya fisik dan logika yang berkenaan dengan objek-objek yang terdapat dipermukaan bumi. SIG selalu diasosiasikan dengan sistem yang berbasis komputer, walaupun pada dasarnya dapat dilakukan secara manual. SIG yang berbasis komputer akan sangat membantu ketika data geografis merupakan data yang besar (dalam jumlah dan ukuran) dan terdiri dari banyak tema yang saling berkaitan. Menurut Chandar dan Karuppasamy (2012) adalah, "Geographic Informations Systems (GIS) digunakan untuk memanipulasi, mamasukkan data, menyimpan data, menganalisis data spasial dan atribut dari berbagai sumber yang digunakan untuk menghasilkan laporan dalam bentuk peta, database, statistik, perhitungan lapangan, dan analisis format teks untuk memfasilitasi pengambilan keputusan".

Konsep dasar SIG merupakan suatu sistem yang mengorganisir perangkat keras (hardware), perangkat lunak (software) dan data serta berfungsi memverifikasi data, menganilisis data, menyimpan data, pengolahan data, memanipulasi data, dan presentasi data sehingga diperoleh informasi yang berkaitan dengan aspek geografis. Data geografis yang dimaksud adalah data spasial yang memiliki ciri sebagai berikut : (1) memiliki titik koordinat dan lokasi 
atau geometric properties. (2) Terkait aspek keruangan seperti kawasan pembangunan, kota atau objek penelitian. (3) berhubungan dengan semua fenomena di bumi seperti data lapangan, kejadian, dan gejala, (4) dipakai untuk analisis, pemantauan ataupun pengelolaan (Nugraha, 2012). SIG juga berperan dalam mengkarakteristikkan sumber daya, mengindentifikasi kesesuaian yang potensial dan mengidentifikasikan konflik antar tujuan-tujuan tertentu pada suatu daerah (Chandar dan Karuppasamy, 2012).

SIG umumnya digunakan menyelesaikan permasalahan atau pertanyaan yang berkaitan dengan lokasi, kondisi, pola, prediksi fenomena, permodelan, dan kecenderungan (Indarto, 2013). Keunikan lainnya dari SIG adalah dimanfaatkan dalam berbagai bidang diantaranya perencanaan wilayah dan kota, pengawasan wilayah bencana alam, manajemen tata kelola lahan, penentuan daerah kerusakan hutan, pengembangan daerah pariwisata dan transportasi, penentuan daerah yang mengalami pencemaran lingkungan, membentuk jalur zonasi penangkapan ikan, penentuan kesesuaian suatu habitat bagi flora dan fauna tertentu dan sesuai dengan kebutuhan yang diingankan.

\subsection{Sistem Pengelolaan Ekosistem Mangrove}

\subsubsection{Pengelolaan Ekosistem Mangrove}

Pengelolaan adalah suatu istilah yang berasal dari kata "kelola" mengandung arti serangkaian usaha yang bertujuan menggali dan memanfaatkan segala potensi yang dimiliki secara efektif dan efesien guna mencapai tujuan tertentu yang telah direncanakan sebelumnya (Harsoyo 1997). Dalam kerangka pengelolaan dan pelestarian mangrove, terdapat dua konsep utama yang 
diterapkan. Kedua konsep tersebut pada dasarnya memberikan legitimasi dan pengertian bahwa mangrove memerlukan pengelolaan dan perlindungan agar dapat tetap lestari. Kedua kosep tersebut adalah perlindungan ekosistem mangrove dan rehabilitasi ekosistem mangrove (Bengen, 2001).

Menurut Bengen (2001), Dalam kerangka pengelolaan dan pelestarian mangrove, terdapat dua konsep utama yang dapat diterapkan yaitu :

1. Perlindungan hutan mangrove

Perlindungan hutan mangrove dilakukan dalam bentuk penunjukan suatu kawasan mangrove untuk menjadi kawasan konservasi dan sebagai suatu bentuk sabuk hijau disepanjang pantai dan sungai.

2. Rehabilitasi hutan mangrove

Salah satu masalah yang timbul dalam upaya pengelolaan dan pelestarian mangrove adalah adanya hak kepemilikan (property rights) sumberdaya pada kawasan mangrove. Hak pemilikan adalah klaim yang sah (secure claim) terhadap sumber daya atau jasa yang dihasilkan dari sumberdaya itu. Hak pemilikan bisa diartikan sebagai suatu karakteristik yang yang memberikan kekuasaan kepada pemilik hak. Perlu diketahui bahwa meski hak pemilikan menyangkut klaim yang sah, hak itu tidak bersifat mutlak. Hak pemilikan dibatasi oleh dua hal yaitu hak orang lain dan ketidaklengkapan (incompleteness). Sebagai contoh: bisa saja kita tidak berhak untuk melakukan penebangan pohon mangrove di areal tambak kita namun orang lain dapat melakukannya. Karakteristik tersebut meliputi ketersediaan manfaat, kemampuan untuk membagi atau mentransfer hak, derajat 
ekslusivitas hak serta durasi penegakan hak (enforceability). Hal ini disebabkan ketidakmampuan kita untuk menebang karena biaya yang mahal.

Rehabilitasi merupakan suatu bentuk atau upaya untuk mengembalikan kondisi ekosistem yang sehat secara ekologis. Bentuk rehabilitasi yang dimaksud dalam konsep ini berupa kegiatan penghijauan yang dilakukan terhadap hutanhutan yang telah gundul. Upaya ini bertujuan untuk mengembalikan fungsi ekologis kawasan hutan mangrove dan memunculkan nilai estetika dari kawasan tersebut.

Anonim (2013), menyatakan upaya terhadap sasaran Strategi Nasional Pengelolaan Ekosistem Mangrove adalah :

1. Tercapainya peningkatan kapasitas para pihak dalam pengelolaan ekosistem mangrove.

2. Tercapainya peningkatan kesadaran dan peran semua pihak yang terkait dalam pengelolaan ekosistem mangrove yang berkelanjutan.

3. Terlaksananya koordinasi dan mekanisme lintas sektor di tingkat pusat dan daerah dalam pengelolaan ekosistem mangrove.

4. Terlaksananya pola pengelolaan berbasis masyarakat dalam pengelolaan ekosistem mangrove

5. Tercapainya peningkatan manfaat dan fungsi ekosistem mangrove bagi sistem penyangga kehidupan.

6. Tercapainya pengurangan laju degradasi ekosistem mangrove dan meningkatnya kualitas ekosistem mangrove di Indonesia. 
Pengelolaan kawasan hutan menjadi tugas pokok pemerintah, yang dalam pelaksanaannya harus melibatkan masyarakat setempat. Undang-Undang nomor 41 tahun 1999 Pasal 2 tentang kehutanan bahwa mangrove merupakan ekosistem hutan, dan oleh karena itu, maka pemerintah bertanggung jawab dalam pengelolaan yang berasaskan manfaat lestari, kerakyatan, keadilan, kebersaman, keterbukaan dan keterpaduan. Selanjutnya dalam kaitan kondisi mangrove yang rusak, kepada setiap orang yang memiliki, pengelola dan atau memanfaatkan hutan kritis atau produksi, wajib melaksanakan rehabilitasi hutan untuk tujuan perlindungan konservasi (Pasal 43). Pada Undang-Undang nomor 5 tahun 1990 tentang konservasi Sumber Daya Alam Hayati dan Ekosistem merupakan suatu kekuatan dalam pelaksanaan konservasi kawasan hutan mangrove, terdapat tiga aspek yang sangat penting yaitu :

1. Perlindungan terhadap sistem penyangga kehidupan dengan menjamin terpeliharanya proses ekologi bagi keberlangsungan hidup biota dan keberadaan ekosistemnya.

2. Pengawetan sumber plasma nutfah yaitu menjamin terpeliharanya sumber genetik dan ekosistem yang sesuai bagi kehidupan umat manusia.

3. Pemanfaatan secara lestari atau berkelanjutan baik berupa produksi dan jasa.

Dalam melakukan suatu pengelolaan mangrove tentu diperlukan tindakantindakan nyata secara signifikan dapat mewujudkan lestarinya mangrove. ada beberapa konsep dan teknik operasional yang dapat dilakukan dalam melakukan konservasi. Salah satunya adalah dengan memanfaatkan mangrove menjadi daerah 
wisata alami tanpa melakukan gangguan signifikan terhadap keberadaan mangrove itu sendiri.

Pengembangan sektor wisata di Indonesia merupakan salah satu usaha dalam menambah pemasukan bagi negara, sehingga memiliki alasan yang kuat untuk dikembangkan. Pada saat ini, pariwisata mulai dikembangkan sesuai dengan wawasan lingkungan, yang sering disebut dengan ekowisata. Pelaksanaan ekowisata di dasari pada pemeliharaan keaslian alam dan lingkungan, pemeliharaan adat istiadat masyarakat yang tinggal pada daerah setempat, serta menjaga kelestarian flora dan fauna yang terdapat pada wilayah tersebut. Prinsip dasar dari ekowisata yaitu : (1) suatu model pengembangan wisata yang yang bertanggung jawab pada daerah yang dikelola dengan kaidah secara alam; (2) dalam menikmati keindahannya, juga melibatkan unsur pendidikan, pemahaman dan dukungan terhadap usaha konservasi sumberdaya alam; dan (3) memilki fungsi sosial, budaya dan ekonomi seperti peningkatan pengetahuan dan pendapatan masayarakat sekitar (Suriani dan Nurdin, 2011).

Terdapat tiga pilihan utama untuk pengelolaan dan pengembangan kawasan hutan mangrove :

1. Perlindungan ekosistem dalam bentuk alaminya

2. Pemanfaatan ekosistem untuk menghasilkan berbagai produk dan jasa yang didasarkan pada prinsip kelestarian.

3. Perubahan (atau perusakan) ekosistem alami, biasanya untuk suatu pemanfaatan tertentu.

Tekanan untuk mengubah areal mangrove untuk penggunaan lain, umumnya berasal dari luar areal tersebut, misalnya perusahaan swasta yang akan 
mengkonversi menjadi tambak, pemerintah yang ingin membangun kawasan pantai untuk daerah pemukiman, industri atau tujuan rekreasi. Fakta pertimbangan ekonomi dan ekologis tidak dapat dipisahkan dalam mengevaluasi berbagai alternatif pengelolaan mangrove (Anonim, 2003).

Saat ini dikembangkan suatu pola pengawasan pengelolaan ekosistem mangrove partisipatif yang melibatkan masyarakat. Ide ini dikembangkan atas dasar pemikiran bahwa masyarakat pesisir yang relatif miskin harus dilibatkan dalam pengelolaan mangrove dengan cara diberdayakan. Pemberdayaan melalui kemampuan ilmu dan ekonominya. Pola pengawasan pengelolaan ekosistem mangrove yang dikembangkan berdarsarkan pola tersebut adalah komponen yang diawasi, sosialisasi, dan transparansi kebijakan, institusi formal, para pihak yang terlibat dalam pengawasan, mekanisme pengawasan, serta insentif dan sanksi (Santoso dan Arifin, 1998).

Untuk pelaksanaannya perlu diketahui kondisi masyarakat yang menyangkut struktur social, bentuk pemanfaatan dan intensitas interaksi masyarakat dengan wilayah pesisir. Selain itu juga perlu dilihat persepsi masyarakat terhadap hutan mangrove dan rencana penanaman yang akan dilaksanakan. Khazali (2005) menyatakan, struktur sosial dan bentuk pemanfaatan serta intensitas interaksi wilayah pesisir oleh masyarakat perlu diketahui agar kelompok target masyarakat yang terlibat dalam kegiatan penanaman, baik prioritas maupun bukan prioritas dapat ditentukan. Sedangkan persepsi masyarakat terhadap hutan mangrove dan rencana penanaman yang akan dilaksanakan penting diketahui untuk memantau pesepsi masyarakat terhadap mangrove. Jika persepsi masyarakat masyarakat negative atau tidak mendukung 
terhadap rencana kegiatan penanaman vegetasi mangrove, maka yang dilaksanakan adalah membangun kesadaran masyarakat akan pentingnya hutan mangrove dan pentingnya manfaat penanaman bagi mereka melalui pendidikan dan penyuluhan.

Menurut Eddy dan Rahim (2013), ada beberapa hal yang dapat dilakukan dalam membangun kesadaran masyarakat antar lain :

1. Diskusi bersama masyarakat untuk memahami kondisi pantai dulu dan sekarang.

2. Mengidentifikasi dan menyadari secara bersama dampak rusak/hilangnya hutan mangrove.

3. Menentukan dan menyepakati bersama solusi mengatasi masalah akibat hilang/rusaknya hutan mangrove.

4. Sosialisasi peraturan-peraturan yang berlaku tentang hutan mangrove.

5. Studi banding untuk meyakini dan memperluas wawasan tentang manfaat hutan mangrove.

6. Perencanaan dan pelaksanaan bersama penanaman mangrove.

7. Pembentukan kelompok masyarakat pengelola dan pelestarian hutan mangrove.

Peran masyarakat dalam pengelolaan mangrove berwawasan ekosistem akan timbul dengan sendirinya apabila masyarakat dapat melihat manfaat secara nyatan tidak hanya fisik maupun ekologi tetapi secara ekonomi.Pengelolaan suatu kawasan, termasuk hutan mangrove, tidak terlepas dari peraturan dan landasan hukum yang ada. Menurut Undang-Undang Nomor 26 Tahun 2007 tentang Penataan Ruang bahwa ekosistem mangrove teramsuk kawasan lindung lainnya, 
yaitu kawasan pesisir berhutan bakau berupa kawasan pesisir laut yang merupakan habitat alami hutan mangrove yang berfungsi memberi perlindungan kepada biota pantai dan laut.

Pendekatan secara bottom-up (Gambar 2.1) merupakan suatu teknik dalam merehabilitasi hutan mangrove, dalam hal ini upaya pemerintah dalam membiayai, sedangkan perencanaan, pelaksanaan, evaluasi keberhasilan, dan pemanfaaatannya secara berkelanjutan dipercayakan kepada masyarakat. Dalam pelaksanaan kegiatan tersebut juga dapat melibatkan lembaga swadaya masyarakat (LSM) bersama perangkat desa, pemangku kepentingan dan lain-lain.

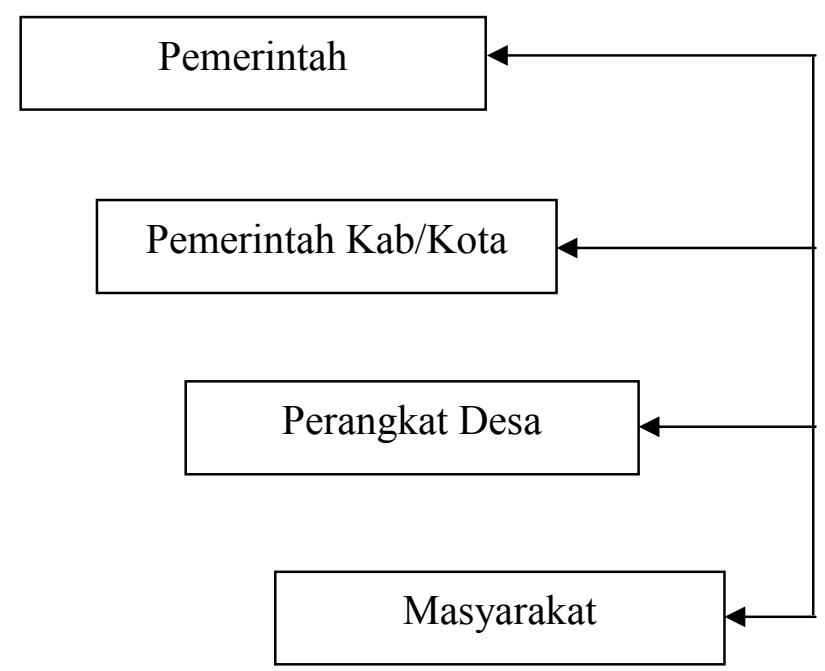

Gambar 2.1 Skema alur pendekatan secara Buttom-up (Rahmawaty, 2006)

Ilmu pengetahuan dan teknologi yang digunakan akan lebih baik jika berorientasi pada tradisi masyarakat pesisir. Kombinsasi antara teknologi dengan pengetahuan tradisional yang sudah terbentuk sebelumnya (kearifan lokal) akan lebih mudah diterima dan dikembangkan oleh masyarakat. 


\subsubsection{Pengertian Ekosistem Mangrove}

Kata mangrove berasal dari bahasa Portugis yaitu mangue yang berarti tumbuhan dan grove (bahasa Inggris) yang berarti belukar atau hutan kecil. Kata mangrove mempunyai dua arti, pertama sebagai komunitas yaitu komunitas atau vegetasi tumbuhan atau hutan yang tahan terhadap kadar garam/salinitas dan kedua sebagai individu spesies (Arief, 2003). Kadang-kadang mangrove juga berarti suatu komunitas mangrove (Romimohtarto dan Juwana, 2001).

Hutan Mangrove adalah tipe hutan yang ditumbuhi dengan pohon mangrove yang khas terdapat di sepanjang pantai atau muara sungai dan dipengaruhi oleh pasang surut air laut (Waas dan Nababan, 2010). Ekosistem hutan mangrove merupakan ekosistem utama dalam mendukung kehidupan wilayah pesisir karena memiliki produktivitas dan kompleksitas dari ekologi lingkungan yang khas, menjadikan ekosistem mangrove memiliki fungsi yang sangat kompleks dari segi fisik, ekologi, ekonomi dan sisoal budaya antara lain fungsi fisik sebagai fasilitator tepian pesisir, pengendali erosi pantai, menjaga stabilitas sedimen, menambah perluasan daratan (land building) dan perlindungan garis pantai (protect agent). Selain itu sebagai kehidupan dan sumber rezeki masyarakat nelayan dan petani di tepi pantai yang sangat tergantung kepada sumber daya alam dari hutan mangrove (Raymond, 2010).

Hutan mangrove adalah hutan yang berkembang baik di daerah pantai yang berair tenang dan terlindung dari hempasan ombak, serta eksitensinya selalu dipengaruhi oleh pasang surut dan aliran sungai. Mangrove merupakan suatu tempat yang bergerak akibat adanya pembentukan tanah lumpur dan daratan 
secara terus menerus oleh tumbuhan sehingga secara perlahan-lahan berubah menjadi semi daratan (Hutabarat dan Evans, 1986). Definisi lain hutan mangrove adalah sustu kelompok tumbuhan terdiri atas berbagai macam jenis dari suku yang berbeda, namun memiliki daya adaptasi morfologi dan fisologis yang sama terhadap habitat yang selalu dipengaruhi oleh pasang surut (Nybakken, 1992).

Ekosistem mangrove terdiri atas dua bagian yaitu bagian daratan dan perairan, yang mana bagian perairan juga terbagi dua yakni bagian tawar dan laut (Romimohtarto dan Juwana, 1999). Hutan mangrove meliputi pohon-pohon dan semak dengan beberapa species yaitu : Avicenia, Sonneratia, Rhyzophora, Brugulera, Cerlops, Xylocarpus, Lumhitzera, Laguncularia, Aegiceras, Aegiatilis, Sneeda, dan Conocarpus (Bengen, 2001)

Hutan mangrove merupakan komunitas vegetasi pantai tropis yang didominasi oleh beberapa jenis mangrove yang mampu tumbuh dan berkembang pada daerah pasang surut pantai berlumpur (Bengen, 2004). Selain itu ekosistem mangrove juga mendapatkan subsidi energi, melalui arus pasang surut yang membantu dalam penyebaran zat-zat hara.

\subsubsection{Karakteristik dan Fungsi Ekosistem Mangrove}

Karakteristik habitat hutan mangrove umumnya tumbuh pada daerah intertidal yang jenis tanahnya berlumpur, berlempung dan berpasir, daerahnya tergenang air secara berkala, baik setiap hari maupun yang hanya tergenang pada saat pasang purnama. Frekuensi genangan menentukan komposisi hutan mangrove, Menerima pasokan air tawar yang cukup dari darat, Terlindung dari gelombang besar dan arus pasang surut yang kuat. Air bersalinitas payau (2-22 
permil) hingga asin (38 permil) (Bengen, 2004). Mangrove tumbuh optimal di wilayah pesisir yang memiliki muara sungai besar dan delta yang aliran airnya banyak mengandung lumpur. Di wilayah pesisir yang tidak bermuara sungai, pertumbuhan vegetasi mangrove tidak optimal. Mangrove sulit tumbuh di wilayah pesisir yang terjal dan berombak besar dengan arus pasang surut kuat karena kondisi ini tidak memungkinkan terjadinya pengendapan lumpur yang diperlukan sebagai substrat bagi pertumbuhannya (Dahuri et al., 1996).

Secara fisik hutan mangrove berfungsi menjaga garis pantai agar tetap stabil, melindungi pantai dari tebing sungai, mencegah terjadi erosi laut, peredam ombak dan sebagai perangkap zat-zat pencemar dan limbah, serta mencegah intrusi garam (salt intrution). Secara biologi hutan mengrove mempunyai fungsi sebagai daerah asuhan (nursery ground), tempat memijah (spawning ground) dan tempat mencari makan untuk berbagai organisme seperti udang, ikan dan kepiting. Secara ekonomi hutan mangrove memiliki fungsi sebagai daerah tambak yang banyak mengandung zat hara, tempat membuat garam, sebagai tempat rekreasi dan penghasil bahan baku industri.

Ekosistem mangrove menjadi habitat dari berbagai jenis burung, mamalia, reptilia dan jenis-jenis biota lainnya, sehingga hutan mangrove memiliki keanekaragaman (biodiversitas) dan plasma nutfah yang tinggi dan berfungsi sebagai salah satu sistem penunjang kehidupan (Mawardi, 2006).

Hutan mangrove, secara spesifik membantu menahan erosi dan abrasi laut dari kerusakan pantai akibat hempasan gelombang air laut. Sementara kondisi ekologis yang mengatur dan melindunginya, sangat tergantung kepada keseimbangan dari persediaan kadar garam dan air tawar, nutrisi yang cukup dan 
substrat yang stabil. Sejumlah pohon mangrove mempunyai sistem perakaran yang istimewa. Rhizophora sp mempunyai akar jangkar yang panjang untuk menopang pohon tersebut dan mencegah semaian di dekatnya. Sonneratia $s p$ dan Avicennia sp mempunyai akar napas berbentuk pasak (akar yang muncul tegak dipermukaan tanah). Bruguiera sp mempunyai akar nafas berbentuk lutut yang memberikan kesempatan bagi oksigen untuk masuk ke sistem perakarannya. Dengan perakaran mangrove yang kuat mampu meredam gerak pasang surut, dan juga mampu terendam dalam air yang kadar garamnya bervariasi. Lebih dari itu, perakaran mangrove dapat mengendalikan lumpur, sehingga mampu memperluas penambahan formasi dan tanah tumbuh (Anwar, et al, 1984).

Salam dan Rachman (1994), mengatakan bahwa daerah mangrove berfungsi sebagai penyangga fisik yang kuat untuk melindungi dan mengurangi terpaan angin, gelombang dan mencegah terjadinya abrasi pantai. Disamping itu hutan mangrove dapat juga mencegah meluasnya penyebaran sedimen kearah laut, sehingga dapat mempertahankan keutuhan ekosistem terumbu karang dan ekosisitem lainnya. Sistem perakaran tanaman mangrove yang bervariasi, seperti akar gantung, akar lutut, akar pipih, akar pinsil dan akar-akar lateral yang memiliki cukup banyak ruang, celah dan lubang lubang yang berfungsi sebagai tempat berlindung bagi jenis-jenis hewan tertentu dari serangan predator. Selain itu komunitas mangrove juga merupakan sumber unsur hara bagi kehidupan hayati (biota perairan laut), serta sumber pakan bagi kehidupan biota darat seperti burung, mamalia dan jenis reptil. Sedangkan jasa mangrove lainnya juga mampu menghasilkan jumlah oksigen lebih besar dibanding dengan tetumbuhan darat (Onrizal, 2002). 


\subsubsection{Zonasi dan Penyebaran Hutan Mangrove}

Pola umum zonasi sering ditemui dari arah laut ke darat, pertama adalah jalur Avicennia spp yang sering berkolompok dengan Sonneratia sp, kemudian jalur Rhizophora spp, Bruguiera sp dan terakhir Nypa sp. Asosiasi di hutan mangrove di Indonesia yaitu, asosiasi antara Bruguiera sp. dan Rhizophora spp. sering ditemukan, terutama di zona terdalam. Segi keanekaragaman jenis, zona transisi (peralihan antara hutan mangrove dan hutan rawa) merupakan zona dengan jenis yang beragam yang terdiri atas jenis-jenis mangrove yang khas dan tidak khas habitat mangrove. Secara umum, sesuai dengan kondisi habitat lokal, tipe komunitas (berdasarkan jenis pohon dominan) mangrove di Indonesia berbeda suatu tempat ke tempat lain dengan variasi ketebalan dari beberapa puluh meter sampai beberapa kilometer dari garis pantai.

Zonasi adalah kondisi dimana kumpulan vegetasi yang saling berdekatan mempunyai sedikit atau tidak ada sama sekali jenis yang sama walaupun tumbuh dalam lingkungan yang sama dan keadaan dimana terdapat perubahan lingkungan yang dapat mengakibatkan perubahan yang nyata diantara kumpulan vegetasi. Lebih lanjut dijelaskan bahwa perubahan vegetasi dapat terjadi dengan batas yang jelas atau tidak jelas atau bisa terjadi bersama-sama (Anwar, et al,1984) dalam Hardiaty (2013). Zonasi dari hutan mangrove mencerminkan tanggapan ekofisiologis tumbuhan mangrove terhadap gradasi lingkungan. Zonasi yang terbentuk berupa zonasi yang sederhana (satu zonasi) dan zonasi yang kompleks (beberapa zonasi) tergantung pada kondisi ekosistem mangrove. Mangrove pada umumnya tumbuh pada 4 (empat) zona adalah sebagai berikut :

1. Zona terbuka 
Zona terbuka berada pada bagian yang berhadapan dengan laut dan komposisi komunitas zona ini tergantung pada substratnya, contohnya adalah Sonneratia alba yang dominan di daerah berapasir sementara Avicenia marina dan Rhizophora mucronata cenderung dominan di daerah yang berlumpur.

2. Zona tengah

Zona tengah berada di belakang zona terbuka. Di zona ini di dominasi oleh jenis Rizophora $s p$ dan jenis-jenis penting lainnya adalah Bruguiera $s p$, Ceriop sp, Excoecaria agallocha, Rizophora mucronata, Xylocarpus granatum dan Xylocarpus moluccensis.

3. Zona berair payau

Zona berair payau berada disepanjang sungai berair payau hingga hampir tawar. Zona ini biasanya didominasi oleh Nypa sp atau Sonneratia sp. Di jalur lain biasanya ditemukan tegakan Nypa fruticans yang bersambung dengan vegetasi yang terdiri dari Cerbera sp, Gluta renghas, Stenochlaena palustris dan Xylocarpus granatum.

4. Zona daratan

Zona daratan berada di zona perairan payau atau hampir tawar dibelakang jalur hijau mangrove sebenarnya. Zona ini memiliki kekayaan jenis yang lebih tinggi dibandingkan dengan zona lainnya, termasuk Ficus microcarpus, FFicus Retusa, Intsia Bijuga, Nypa Fruticans, Lumnitza recemoza, Pandanus sp dan Xylocarpus moluccensis.

Faktor utama yang menyebabkan adanya zonasi pada hutan mangrove adalah sifat-sifat tanah, sedangkan factor yang lain yaitu salinitas, frekuensi serta tingkat penggenangan dan ketahanan suatu jenis terhadap ombak dan arus, 
sehingga variasi zonasi ini memanjang dari daratan sampai ke pantai. Dari segi keanekaragaman jenis, zona transisi (peralihan antara hutan mangrove dan hutan rawa) merupakan zona dengan jenis yang beraneka ragam yang terdiri atas jenisjenis mangrove yang khas dan tidak khas habitat mangrove.

Mangrove di Indonesia memiliki keanekaragaman jenis yang tinggi, yang seluruhnya tercatat sebanyak 202 jenis tumbuhan (Bengen, 2000). Jenis pohon dan zonasi tumbuhan mangrove memiliki berbagai variasi pada lokasi yang berbeda, ditentukan oleh jenis tanah, kedalaman dan periode genangan, kadar garam dan daya tahan terhadap ombak serta arus (Nontji, 2002).

Salah satu tipe zonasi hutan mangrove di Indonesia seperti ditujukkan pada Gambar 2.2, yaitu daerah yang paling dekat dengan laut, dengan substrat agak berpasir, sering ditumbuhi oleh Avicennia sp. Pada zona ini biasa berasosiasi dengan Sonneratia sp yang dominan tumbuh pada lumpur yang dalam yang agak kaya dengan bahan organik. Lebih ke arah darat, hutan mangrove umumnya didominasi oleh Rhizophora sp, di zona ini juga dijumpai Bruguiera sp dan Xylocarpus sp. Zona berikutnya didominasi oleh Bruguiera sp. Zona transisi antara hutan mangrove dengan hutan daratan rendah biasa ditumbuhi oleh Nypa fruticans dan beberapa spesies palem lainnya (Bengen, 2000). 


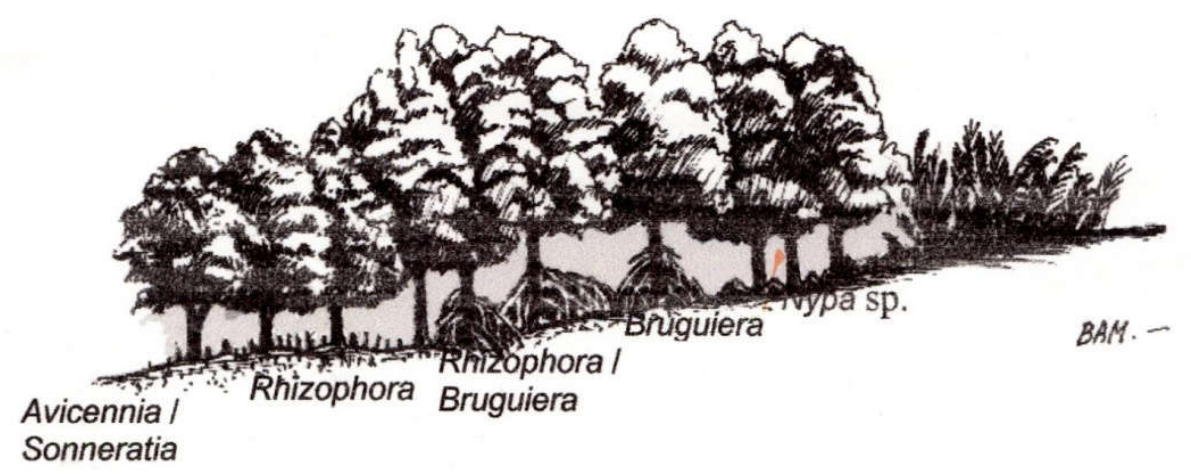

Gambar 2.2 Salah satu tipe zonasi hutan mangrove di Indonesia (Eddy dan Rahim, 2013)

Tidak semua tumbuh-tumbuhan memperoleh oksigen untuk akar-akarnya dari tanah yang mengandung oksigen, mangrove tumbuh di tanah yang tidak mengandung oksigen dan harus memperoleh hampir seluruh oksigen untuk akarakar mereka dari atmosfer (Gambar 2.3). Spesies Rhizophora memenuhi kebutuhan tersebut dengan akar-akar tunjang yang mencuat sampai mempunyai banyak pori-pori yang disebut lentisel. Pada waktu air surut, oksigen terserap ke dalam tanaman melalui lentisel dan turun ke akar-akar. Berbeda dengan Rhizophora, jenis Sonneratia, Avicennia dan Xylocarpus tidak memiliki akar-akar tunjang, tetapi mempunyai pneumatophores, yaitu akar- akar yang mencuat secara vertikal ke luar dari bawah tanah. Pada waktu surut, udara masuk melalui pneumatophore dan menyebarkan ke bawah selanjutnya ke seluruh jaringan hidup di akar (Supriharyono, 2000). 


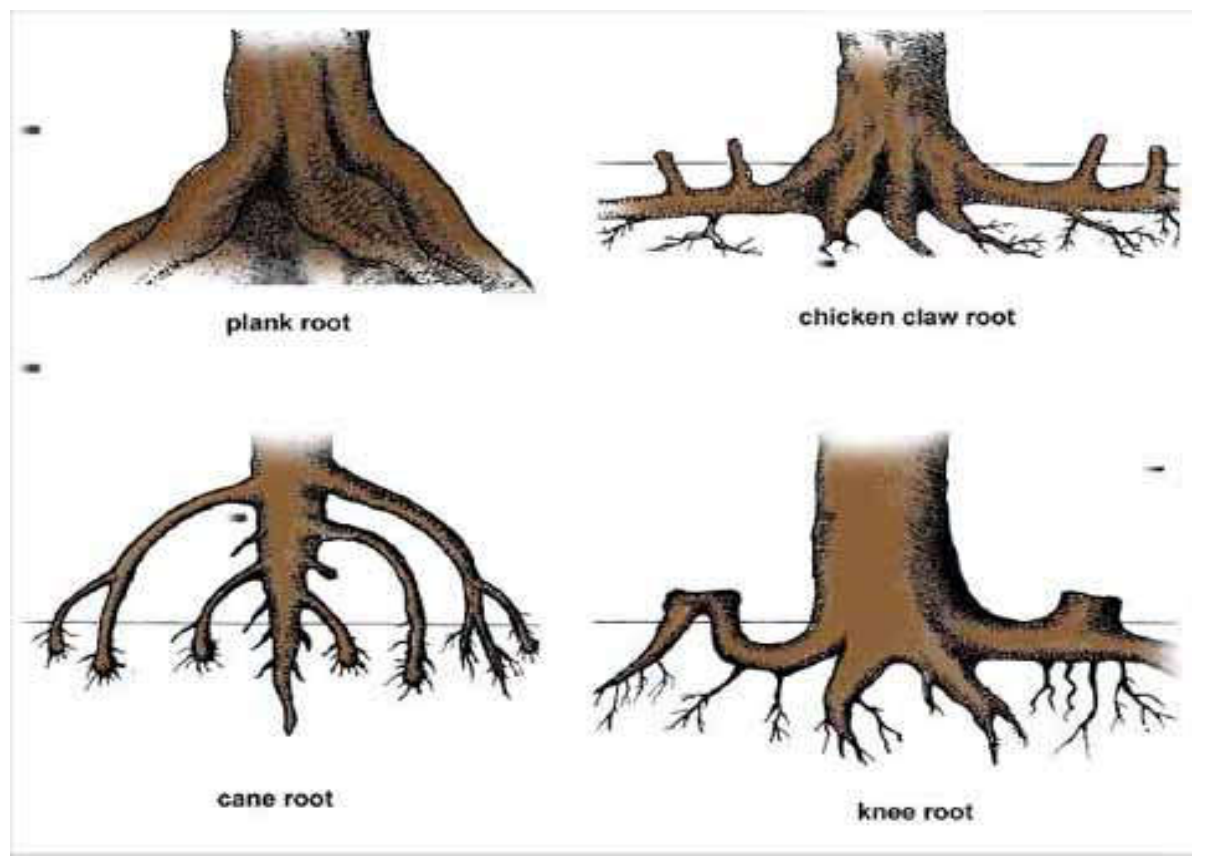

Gambar 2.3 Bentuk akar tumbuhan hutan mangrove reproduktif (Eddy dan Rahim, 2013)

Adaptasi vegetasi hutan mangrove yang unik menyebabkan mangrove dapat tumbuh pada daerah yang cukup ekstrim bagi sebagian besar tanaman, yaitu daerah dengan kadar oksigen rendah, salinitas (kadar garam) yang tinggi dan dipengaruhi pasang surut air laut. Menurut Bengen (2002) dalam Eddy dan Rahim (2013), adaptasi vegetasi hutan mangrove dilakukan dengan beberapa cara, yaitu:

a. Adaptasi terhadap kadar oksigen rendah; dengan memiliki bentuk perakaran yang khas gambar 2.3 (tipe cakar ayam/pasak dengan pneumatofora dan tipe tongkat/tunjang dengan lentisel untuk mengambil oksigen dari udara).

b. Adaptasi terhadap kadar garam tinggi; memiliki sel-sel khusus dalam daun untuk menyimpan garam, daun tebal dan kuat yang banyak mengandung air untuk menjaga keseimbangan garam dan memiliki stomata khusus untuk mengurangi penguapan. 
c. Adaptasi terhadap tanah yang tidak stabil dan pasang surut; mengembangkan struktur akar yang sangat ekstensif dan membentuk jaringan horizontal yang lebar untuk memperkokoh pohon dan mengambil unsur hara serta menahan sedimen.

\subsubsection{Jalur Hijau Hutan Mangrove}

Jalur hijau adalah zona perlindungan mangrove yang dipertahankan di sepanjang pantai dan tidak diperbolehkan untuk ditebang, dikonversikan atau dirusak. Fungsi jalur hijau pada prinsipnya untuk mempertahankan pantai dari ancaman erosi serta untuk mempertahankan fungsi mangrove sebagai tempat berkembangbiak dan berpijah berbagai jenis ikan. Secara ekologis, lebar jalur hijau mangrove seyogyanya ditentukan secara spesifik untuk setiap lokasi karena setiap tempat mempunyai karakteristik lingkungan yang spesifik.

Tujuan dari pengelolaan hutan mangrove sebagai jalur hijau antara lain adalah sebagai berikut:

a. Melestarikan ekosistem hutan mangrove dalam kaitanya sebagai satu kesatuan ekologis (ecological entity).

b. Mempertahankan terselenggaranya proses-proses yang berperan terhadap produktifitas sumberdaya hayati perairan estuaria maupun sistem perairan sekitarnya, mencakup perairan pesisir, perairan sungai dan rawa.

c. Melindungi garis pantai khususnya dan garis tepian perairan umumnya, terhadap pengikisan arus atau abrasi akibat gerakan air. Mempertahankan keseimbangan zona perairan pesisir, mencegah perembesan air garam ke arah daratan. 


\subsection{Ekowisata}

Ekowisata merupakan perjalanan wisata ke suatu lingkungan baik alam yang alami maupun buatan serta budaya yang ada yang bersifat informatif dan partisipatif yang bertujuan untuk menjamin kelestarian alam dan sosial-budaya. Ekowisata menitikberatkan pada tiga hal utama yaitu; keberlangsungan alam atau ekologi, memberikan manfaat ekonomi, dan secara psikologi dapat diterima dalam kehidupan sosial masyarakat. Kegiatan ekowisata secara langsung memberi akses kepada semua orang untuk melihat, mengetahui, dan menikmati pengalaman alam, intelektual dan budaya masyarakat lokal. Kegiatan ekowisata dapat meningkatkan pendapatan untuk pelestarian alam yang dijadikan sebagai obyek wisata ekowisata dan menghasilkan keuntungan ekonomi bagi kehidupan masyarakat yang berada di daerah tersebut atau daerah setempat (Subadra, 2008). Sedangkan Fandeli (2002) menjelaskan sebagai suatu perpaduan dari berbagai minat yang tumbuh dari keprihatinan lingkungan, ekonomi, dan sosial.

Menurut Mawardi (2006) ada 3 dimensi penting dalam ekowisata, yaitu :

1. Konservasi : suatu kegiatan waisata untuk membantu usaha pelestarian alam setempat dengan dampak negatif seminimal mungkin.

2. Pendidikan : wisatawan yang mengikuti wisata tersebut akan mendapatkan ilmu pengetahuan mengenai keunikan biologis, ekosistem dan kehidupan sosial di kawasan yang dikunjungi.

3. Sosial : masyarakat mendapat kesempatan untuk menjalankan kesempatan tersebut.

Ekowisata saat ini menjadi salah satu pilihan dalam mempromosikan lingkungan yang khas yang terjaga keasliannya sekaligus menjadi suatu kawasan 
kunjungan wisata. Suatu kawasan akan bernilai lebih dan menjadi daya tarik tersendiri bagi orang jika di dalamnya terdapat suatu yang khas dan unik untuk di lihat dan di rasakan. Ini menjadi kunci dari suatu pengembangan kawasan wisata (Kasim, 2006). Potensi yang ada adalah suatu konsep pengembangan lingkungan yang berbasis pada pendekatan pemeliharaan dan konservasi alam, mangrove sangat potensil bagi pengembangan ekowisata karena kondisi mangrove yang sangat unik serta model wilayah yang dapat di kembangkan sebagai sarana wisata dengan tetap menjaga keaslian hutan serta organisme yang hidup kawasan mangrove.

\subsubsection{Ekowisata Mangrove}

Ekowisata mangrove adalah kawasan yang diperuntuhkan secara khusus untuk dipelihara untuk kepentingan pariwisata. Saat ini wisatawan sangat peka terhadap permsalahan lingkungan, sehinga diperlukan sebuah konsep pengambangan objek kepariwisataan. Salah satu konsep pariwisata yaitu ekowisata yang sedang marak diterapkan. Kawasan hutan mangrove adalah salah satu kawasan pantai yang memiliki keunikan dan kekhasan tersendiri, karena keberadaan ekosistem ini berada pada muara sungai atau estuaria. Mangrove hanya tumbuh dan menyebar pada daerah tropis dan subtropis dengan kekhasan organisme baik tumbuhan yang hidup dan berasosiasi disana. Dalam melakukan suatu pengelolaan mengrove tentu saja diperlukan tindakan-tindakan nyata yang secara signifikan dapat mewujudkan lestarinya mangrove. Salah satunya adalah dengan memanfaatkan mangrove menjadi daerah wisata alami tanpa melakukan ganguan signifikan terhadap keberadaan mangrove. 
Ekosistem mangrove merupakan habitat bagi berbagai fauna, baik fauna khas mangrove maupun fauna yang berasosiasi dengan mangrove. Berbagai fauna tersebut menjadikan mangrove sebagai tempat tinggal, mencari makan, bermain atau tempat berkembang biak. Komunitas fauna mangrove terdiri dari dua kelompok yaitu :

1. Kelompok fauna daratan/terestial yang umumnya menempati bagian atas pohon mangrove, terdiri atas: insekta, ular, primata dan burung. Kelompok ini tidak mempunyai sifat adaptasi khusus untuk hidup di dalam hutan mangrove, karena mereka melewatkan sebagian besar hidupnya di luar jangkauan air laut pada pohon yang tinggi, meskipun mereka dapat mengumpulkan makanannya berupa hewan laut pada saat air surut.

2. Kelompok fauna akuatik/perairan, terdiri atas dua tipe, yaitu: (1) yang hidup di kolom air, terutama jenis ikan dan udang (2) yang menempati substrat baik keras (akar dan batang mangrove) maupun lunak (lumpur) terutama kepiting, kerang dan berbagai jenis invertebrata lainnya.

Oleh karena itu pengelolaan ekosistem mangrove harus di lakukan secara berkelanjutan, yaitu dengan memperhatikan lingkungan, masyarakat dan pergerakan perekonomian yang terjadi sebelum dan selama ekowisata dijalankan. Ekowisata mampu memberikan konstribusi secara lansung melalui konservasi, yang artinya mendapatkan dana untuk menyokong kegiatan konservasi dan pengelolaan lingkungan, termasuk didalamnya penelitian untuk pengembangan. Selain itu, kontribusi secara tidak lansung melalui konservasi untuk meningkatnya kesadaran publik terhadap konservasi pada tingkat lokal, nasional dan internasional. 


\subsubsection{Prinsip dan Karakteristik Ekowisata}

Prinsip dasar ekowisata di indonesia menurut Zalukhu (2009) dirumuskan sebagai berikut :

1. Pelestarian.

Prinsip pelestarian pada ekowisata adalah kegiatan ekowisata yang dilakukan tidak menimbulkan kerusakan dan pencemaran lingkungan dan budaya setempat. Salah satu cara menerapkan prinsip ini adalah dengan cara menggunakan sumber daya lokal yang hemat energi dan dikelola oleh masyarakat sekitar. Tak hanya masyarakat, tapi wisatawan juga harus menghormati dan turut serta dalam pelestarian alam dan budaya daerah yang dikunjungi.

2. Pendidikan.

Kegiatan pariwisata yang dilakukan sebaiknya memberikan unsur pendidikan, misalnya memberikan informasi menarik seperti nama dan manfaat tumbuhan dan hewan yang ada di sekitar daerah wisata.

3. Pariwisata.

Pariwisata adalah aktivitas yang mengandung unsur kesenangan dengan berbagai motivasi wisatawan untuk mengunjungi suatu lokasi.

4. Perekonomian.

Ekowisata yang dijalankan harus memberikan keuntungan (profit). Untuk dapat mewujudkan hal itu, yang penting untuk dilakukan adalah memberikan pelayanan dan produk wisata yang berkualitas.

5. Partisipasi masyarakat setempat. 
Partisipasi masyarakat akan timbul, ketika alam/budaya itu memberikan manfaat lansung/tidak lansung bagi masyarakat. Partisipasi masyarakat penting bagi suksesnya ekowisata disuatu daerah tujuan ekowisata. Partisipasi dalam kegiatan pariwisata akan memberikan manfaat lansung bagi kita, baik untuk pelestarian alam maupun ekonomi. Bila kita yang menjaga alam tetap bersih, maka kita sendiri yang akan menikmati kelestarian tersebut, bila kita berperan dalam kegiatan pariwisata, maka kita juga yang akan mendapatkan manfaatnya secara ekonomi.

Sedangkan karakteristik ekowisata menurut Damani dan Helmut (2006) dalam Aswita (2014) adalah :

1. Aktivitas wisata yang berkaitan dengan konservasi lingkungan, meskipun hal tersebut bukan tujuan utama dari para wisatawan.

2. Wisata berbasis lingkungan dan alam.

3. Pengeorganisasian perjalanan menunjukkan tanggung jawab financial dalam pelestarian lingkungan.

4. Kegiatan wisata yang dilakukan tidak hanya bertujuan untuk menikmati keindahan dan kekayaan alam semata, tetapi juga mengumpulkan dana yang akan digunakan bagi pelestarian alam.

5. Perjalanan wisata menggunakan alat transportasi dan akomodasi lokal.

6. Pendapatan dari pariwisata digunakan tidak hanya untuk mendukung kegiatan konservasi lokal tetapi juga membantu pengembangan masyarakat setempat secara berkelanjutan.

7. Perjalanan wisata menggunakan teknologi sederhana yang tersedia di daerah tujuan wisata, menghemat energi dan menggunakan sumberdaya lokal. 
8. Kecil wisata berskala kecil, baik dari jumlah wisatawan dan jasa yang dikelola, serta perolehan keuntungan yang cenderung lebih kecil. 
BAB III

\section{METODE PENELITIAN}

\subsection{Gambaran Umum Lokasi Penelitian}

Secara astronomis Kecamatan Kutaraja terletak pada $5^{\circ} 33^{\prime} 8,834^{\prime \prime}-5^{\circ}$ $35^{\prime} 6,708^{\prime \prime}$ Lintang Utara dan $95^{\circ} 18^{\prime} 18,648^{\prime \prime}-95^{\circ} 19^{\prime} 23,044^{\prime \prime}$ Bujur Timur. Luas wilayah Kecamatan Kuta Raja 358,47 Ha dan luas lokasi penelitian adalah 291,42 Ha. Batas administrasi Kecamatan Kuta Raja adalah :

a. Sebelah Utara berbatasan dengan Selat Malaka.

b. Sebelah Timur berbatasan dengan Krueng Aceh, Kecamatan Kuta Alam.

c. Sebelah Selatan berbatasan dengan Kecamatan Baiturrahman dan Kecamatan Meuraxa.

d. Sebelah Barat berbatasan dengan Kecamatan Meuraxa. 

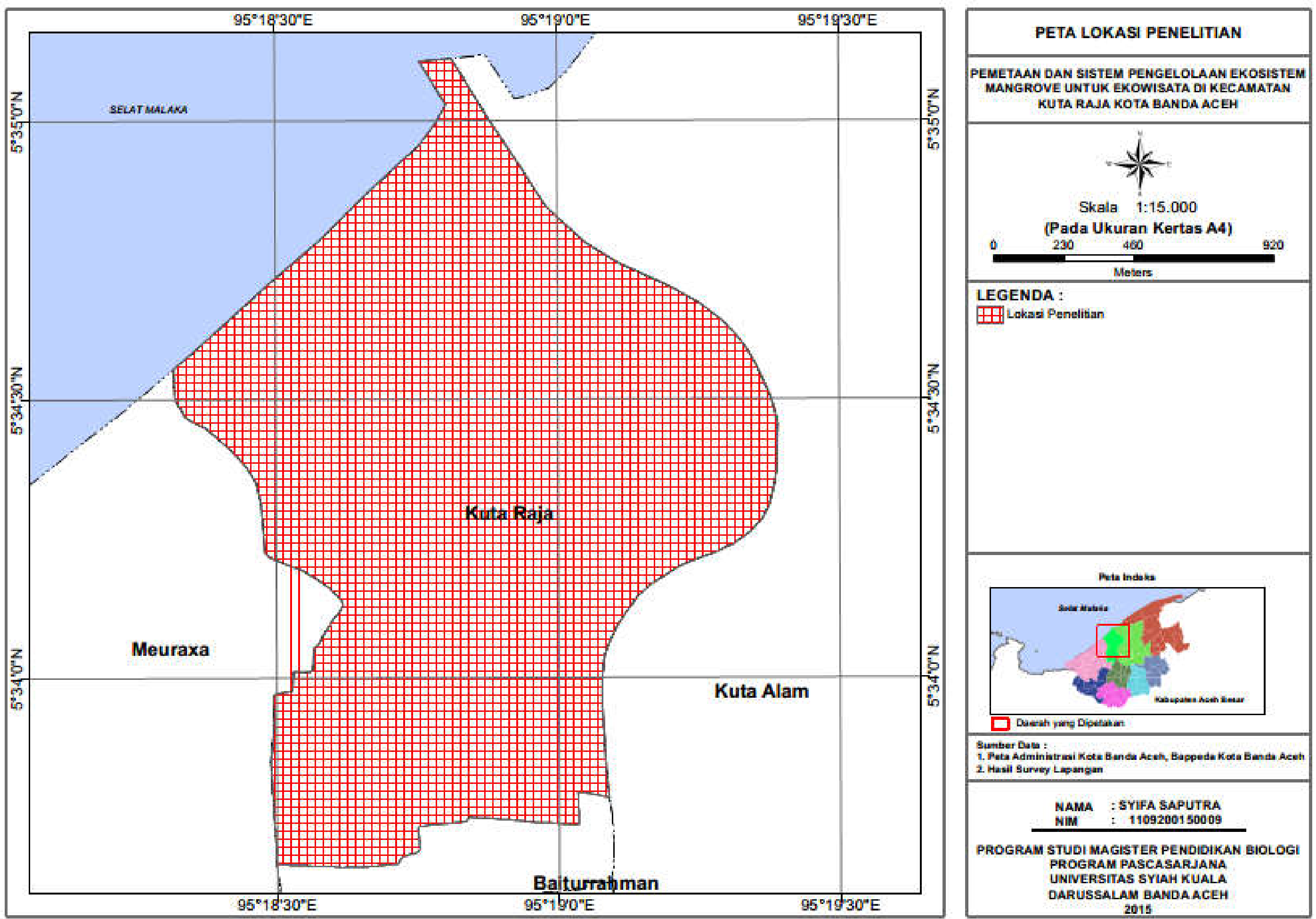

LEGENDA :

田 Lokasi Penelitian

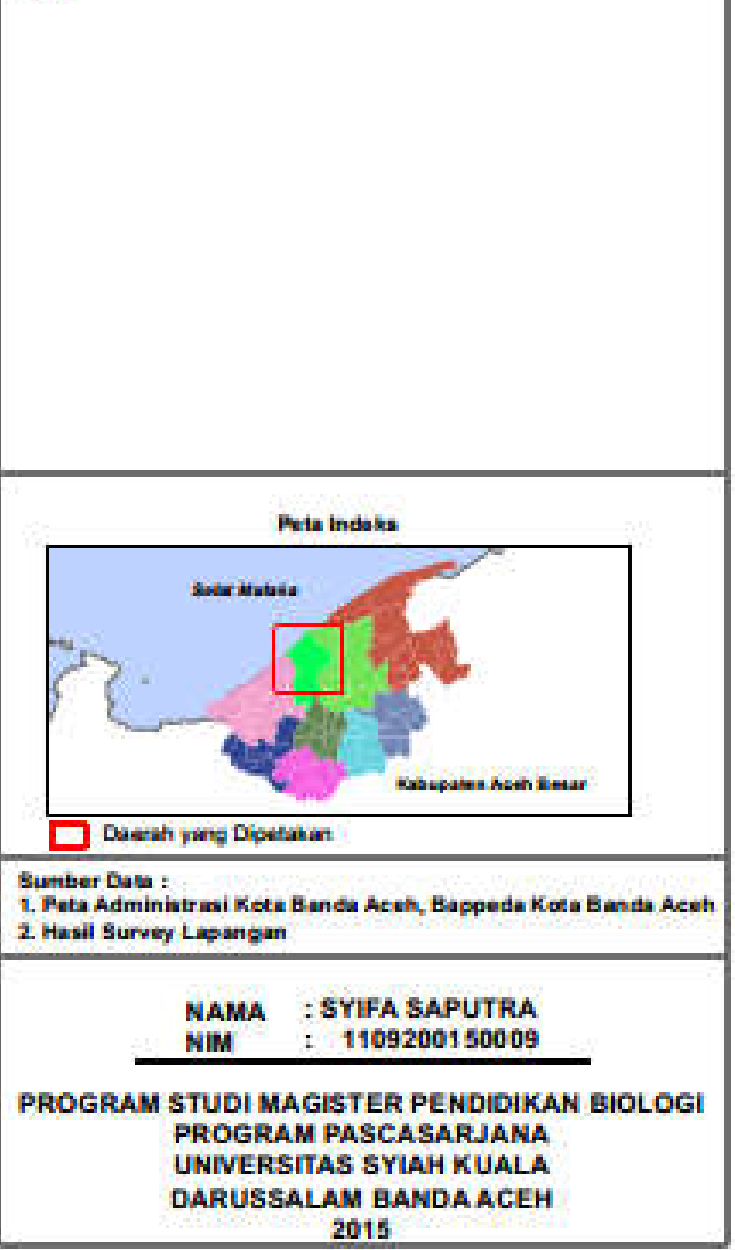




\subsection{Tempat dan Waktu penelitian}

Penelitian ini dilakukan di Kecamatan Kuta Raja Kota Banda Aceh (Gambar 3.1) merupakan salah satu daerah yang mempunyai ekosistem mangrove yang meliputi 3 Gampong yaitu Gampong Peulanggahan, Gampong Pande dan Gampong Jawa. Penelitian ini dilaksanakan pada bulan April - Mei 2015.

\subsection{Alat Dan Bahan Penelitian}

Dalam survei lapangan dan pengolahan data, alat bantu yang digunakan adalah :

Tabel. 3.1. Alat dan bahan yang digunakan dalam penelitian lapangan

\begin{tabular}{llcl}
\hline No Nama & Spesifikasi & $\begin{array}{c}\text { Jumlah } \\
\text { kebutuhan }\end{array}$ & Kegunaan \\
\hline
\end{tabular}

\begin{tabular}{|c|c|c|c|c|}
\hline A. & Alat & & & \\
\hline 1. & Seperangkat PC & - & 1 Unit & $\begin{array}{l}\text { Untuk mengedit dan } \\
\text { mengeloh data penelitian }\end{array}$ \\
\hline 2. & Printer & $\begin{array}{l}\text { Epson } \\
\text { L210 }\end{array}$ & 1 Unit & $\begin{array}{l}\text { Untuk mencetak hasil } \\
\text { penelitian }\end{array}$ \\
\hline 3. & Software GIS & Versi 9.3 & - & Untuk pembuatan peta \\
\hline 4. & $\begin{array}{l}\text { Global Position } \\
\text { System (GPS) }\end{array}$ & $\begin{array}{l}\text { Garmin } \\
72 \mathrm{H}\end{array}$ & 1 Unit & $\begin{array}{l}\text { Untuk pengambilan titik } \\
\text { koordinat }\end{array}$ \\
\hline 5. & Alat Tulis & - & 1 set & $\begin{array}{l}\text { Untuk mencatat berbagai } \\
\text { penelitian }\end{array}$ \\
\hline 6. & Kamera Digital & Canon & 1 unit & $\begin{array}{l}\text { Untuk mendokumentasikan } \\
\text { hasil lapangan }\end{array}$ \\
\hline B. & Bahan & & & \\
\hline 1. & $\begin{array}{l}\text { Peta lokasi } \\
\text { penelitian }\end{array}$ & $\begin{array}{l}\text { Format } \\
\text { JPG }\end{array}$ & 1 Unit & $\begin{array}{l}\text { Untuk menunjukkan lokasi } \\
\text { penelitian. }\end{array}$ \\
\hline 2. & $\begin{array}{l}\text { Lembar } \\
\text { Observasi }\end{array}$ & - & Secukupnya & $\begin{array}{l}\text { Untuk mendata dan } \\
\text { mendiskripsikan seluruh } \\
\text { parameter penelitian. }\end{array}$ \\
\hline
\end{tabular}




\subsection{Rancangan Penelitian}

Langkah-langkah penelitian ini dibagi dalam empat tahapan, yaitu : (1)

Tahap Persiapan, (2) Tahap Pengumpulan data dan tahap pembuatan peta tematis.

1. Tahap persiapan/awal

Pada tahap ini dilakukan pengumpulan literatur pendukung yang berkaitan dengan objek penelitian. Data yang digunakan dalam penelitian ini adalah data primer dan data sekunder (Gambar 3.1). Pengumpulan data primer dilakukan melalui pengamatan lansung di lapangan, dengan melakukan identifikasi jenis-jenis mangrove dan wawancara dengan masyarakat di seputaran mangrove, untuk mengetahui pemahaman masyarakat dalam mengelola ekosistem mangrove di Kuta Raja Kota Banda Aceh. Sedangkan untuk data sekunder yaitu dengan cara mengumpulkan dokumen yang berkaitan dengan penelitian, peraturan perundang-undangan, data dari Balai Mangrove Provinsi Aceh dan Bappeda Kota Banda Aceh.

2. Tahap pengumpulan data dan tahap pembuatan peta

Pengumpulan data dilakukan dengan metode survei dan observasi lapangan serta melakukan pencatatan titik koordinat dengan menggunakan lembar observasi (Gambar 3.1). Setelah data terkumpul maka dilakukan tahap pemetaan dengan menggunakan software sistem informasi geografis. 


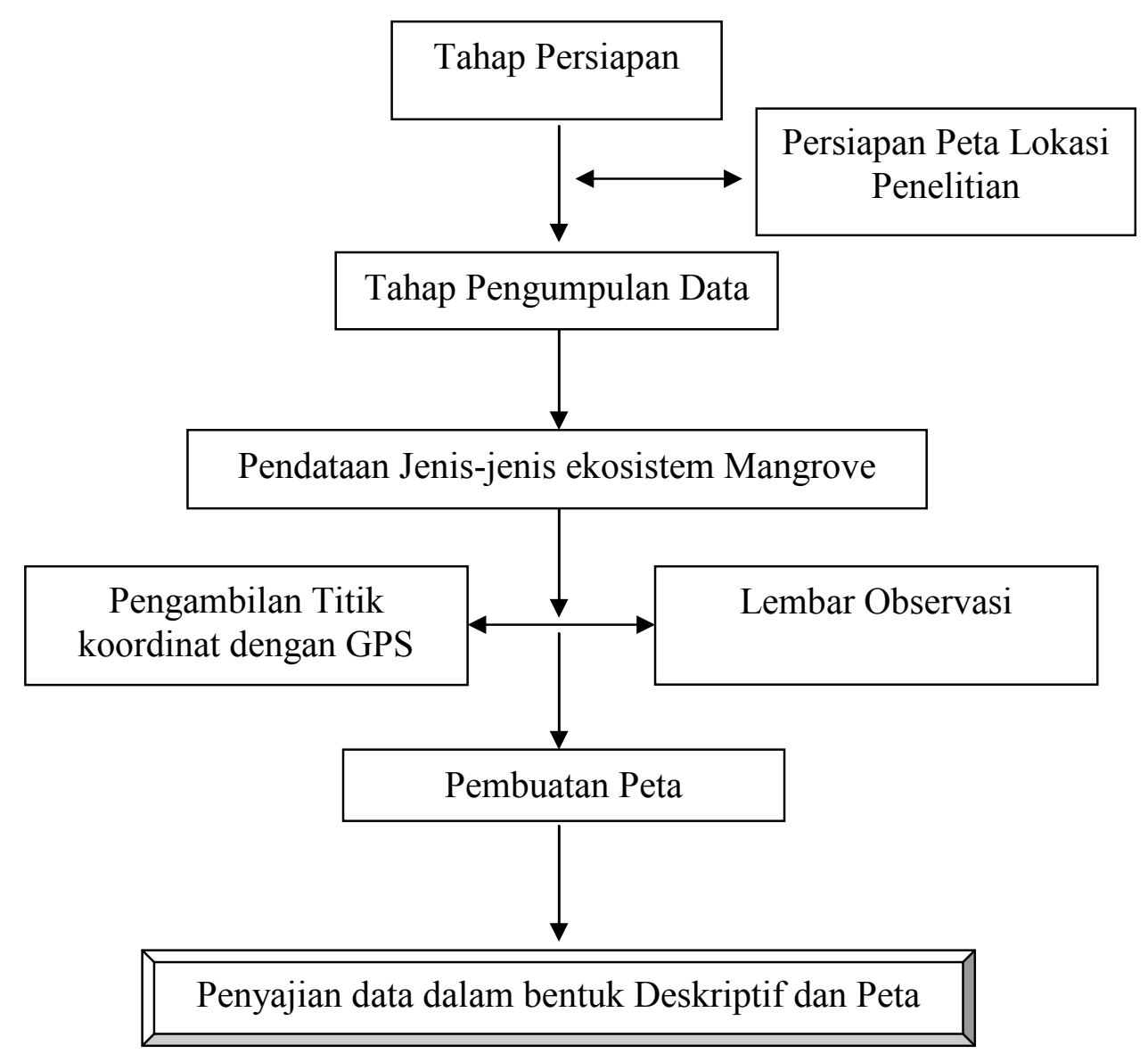

Gambar 3.2 Diagram Alur Penelitian

\subsection{Pendekatan, Metode dan Jenis penelitian}

Pendekatan dan jenis penelitian adalah deskriptif dengan menggunakan metode survei. Penggunaan metode ini bertujuan untuk memetakan sistem pengelolaan ekosistem mangrove, keragaman jenis mangrove dan kondisi fisik yang dimiliki oleh wilayah tersebut. Data yang dikumpulkan terdiri dari jenis ekosistem mangrove, jenis satwa khas pantai, dan kondisi fisik lokasi penelitian, yang diperoleh melalui observasi lapangan yang disertai dengan penetuan titik koordinat pada setiap titik pengamatan. 


\subsection{Objek penelitian}

Objek penelitian adalah jenis tumbuhan mangrove, dan jenis satwa yang ada di ekosistem mangrove. Pengamatan objek penelitian ini juga disertai dengan pengambilan titik koordinat dengan menggunakan GPS.

\subsection{Parameter Penelitian}

Parameter dalam penelitian ini adalah :

1. Jenis-jenis mangrove yang terdapat di lokasi penelitian

2. Jenis biota ekosistem mangrove seperti : burung, reptil, ikan, crustacea, dan serangga.

\subsection{Tekhnik Pengumpulan Data}

Pengumpulan data dilakukan untuk mendapatkan informasi yang lengkap berkaitan dengan faktor pemilihan lokasi untuk ekowisata terhadap sistem pengelolaan ekosistem mangrove, terdiri dari :

a. Mengidentifikasi jenis-jenis mangrove dan jenis biota ekosistem mangrove disertakan dengan pencatatan titik koordinat dengan menggunakan lembar observasi.

b. Dokumentasi, menyajikan dalam bentuk foto kegiatan, jenis ekosistem mangrove, dan pemetaan ekowisata mangrove. 


\subsection{Analisis Data}

Data yang telah dikumpulkan dijelaskan secara deskriptif untuk mengetahui sistem pengelolaan ekosistem mangrove untuk ekowisata dan selanjutnya ditampilkan dalam bentuk peta dengan menggunakan software SIG. Pemetaan dilakukan dengan menggunakan peta dasar dan diperbaharui dengan data - data titik koordinasi yang diambil dilapangan. Proses pemetaan dengan GIS dilakukan dengan survei dan observasi, untuk pengukuran luas dilakukan dengan menggunakan peta tahun 2004 sebelum tsunami dan peta 2015 sesudah tsunami. Sedangkan untuk pengamatan fauna dilakukan dengan cara identifikasi lansung sehingga jenis-jenis yang muncul diambil gambarnya untuk dokumentaso kegiatan. 


\section{BAB IV}

\section{HASIL DAN PEMBAHASAN}

\subsection{Kondisi Ekosistem Mangrove Wilayah Penelitian}

Hutan mangrove di Kecamatan Kuta Raja pada tahun 2004 (Gambar 4.1) sebelum tsunami memiliki luas 66,25 Ha sedangkan luas hutan mangrove pada tahun 2015 setelah tsunami (Gambar 4.2) adalah 47,9 Ha. Hal ini disebabkan oleh gelombang tsunami pada tahun 2004, terutama yang berada di bagian pesisir, mengalami kerusakan yang cukup parah dengan banyaknya jumlah korban jiwa, hancurnya sarana dan prasarana serta ekosistem mangrove. Hutan mangrove sebelum tsunami pada umumnya tumbuh secara alami yang tersebar di sepanjang garis pantai sehingga masih terjaga kelestarian ekosistemnya. Mangrove sebelum tsunami ada 6 (enam) Jenis yaitu Rhizophora apiculata, Rhizophora mucronata, Xylocarpus granatum, Avicenia sp, Sonneratia alba, Nypa frutycan dan tersebar di Gampong Pande, Gampong Peulanggahan dan Gampong Jawa. Adapun jenis mangrove sebelum tsunami 2004 dan sesudah tsunami 2015 disajikan pada tabel 4.1. 


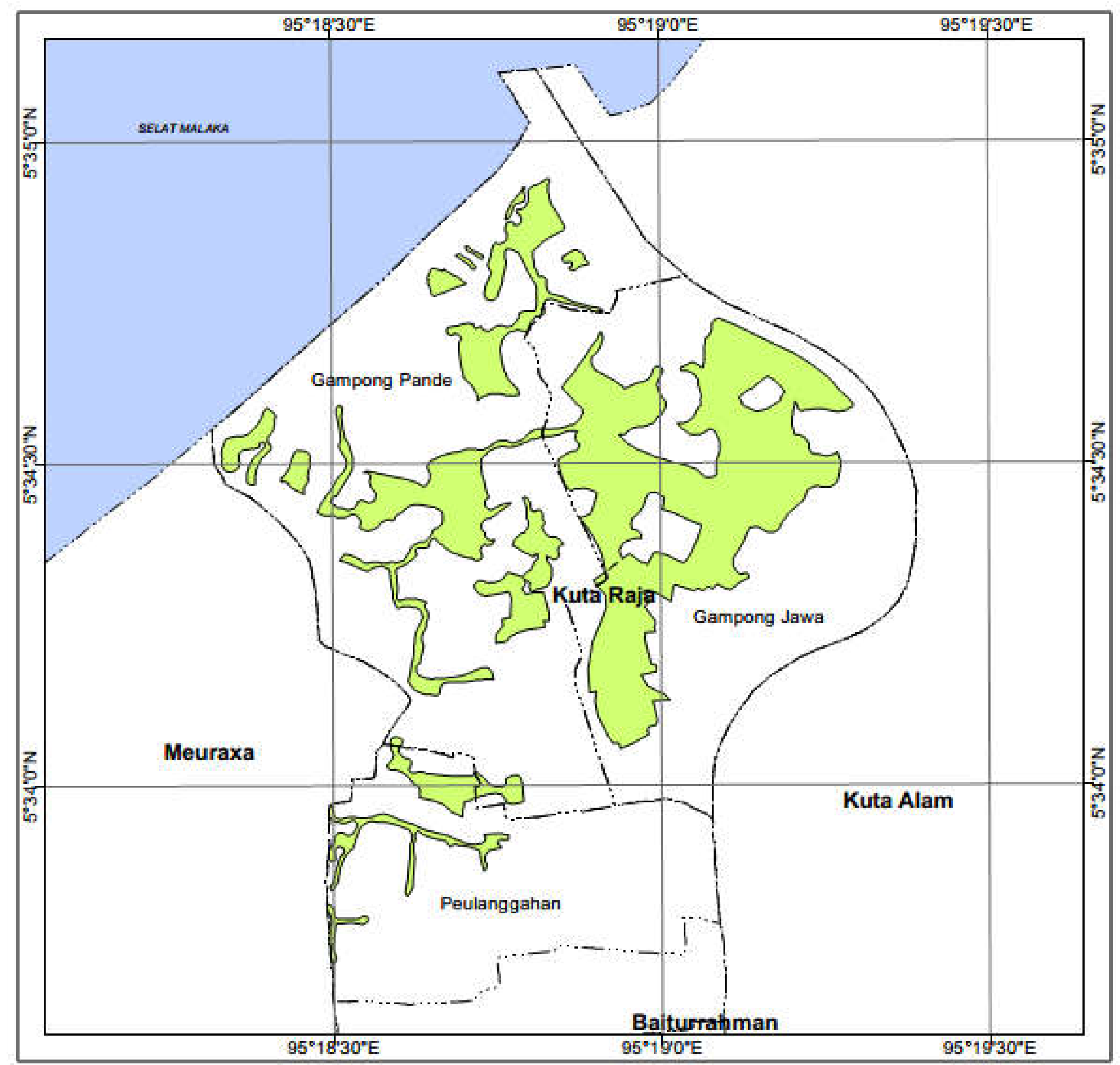

PETA SEBARAN MANGROVE TAHUN 2004

PEMETAAN DAN SISTEM PENGELOLAAN EKOSISTEM MANGROVE UNTUK EKOWISATA DI KECAMATAN KUTA RAJA KOTA BANDA ACEH

$$
\frac{d k}{15}
$$

Skala 1:15.000

(Pada Ukuran Kertas A4) Mevers

\section{LEGENDA :}

-...- Bam Kecarna

-.... Antan Den.

\section{Neia indaka}

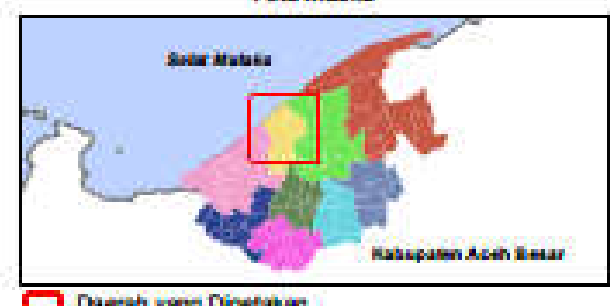

$\square$ Daesh pies Diptation

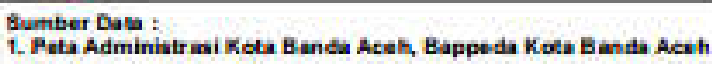
2 Haxil Survey Lapangea

NAMA : SYIFA SAPUTRA
NIM : 1109200150009

PROGRAM STUDI MAGISTER PENDIDIKAN BIOLOGI PROGRAM PASCASARJANA UNIVERSTAS SYIAH KUALA DARUSSALAM BANDA ACEH 2015 


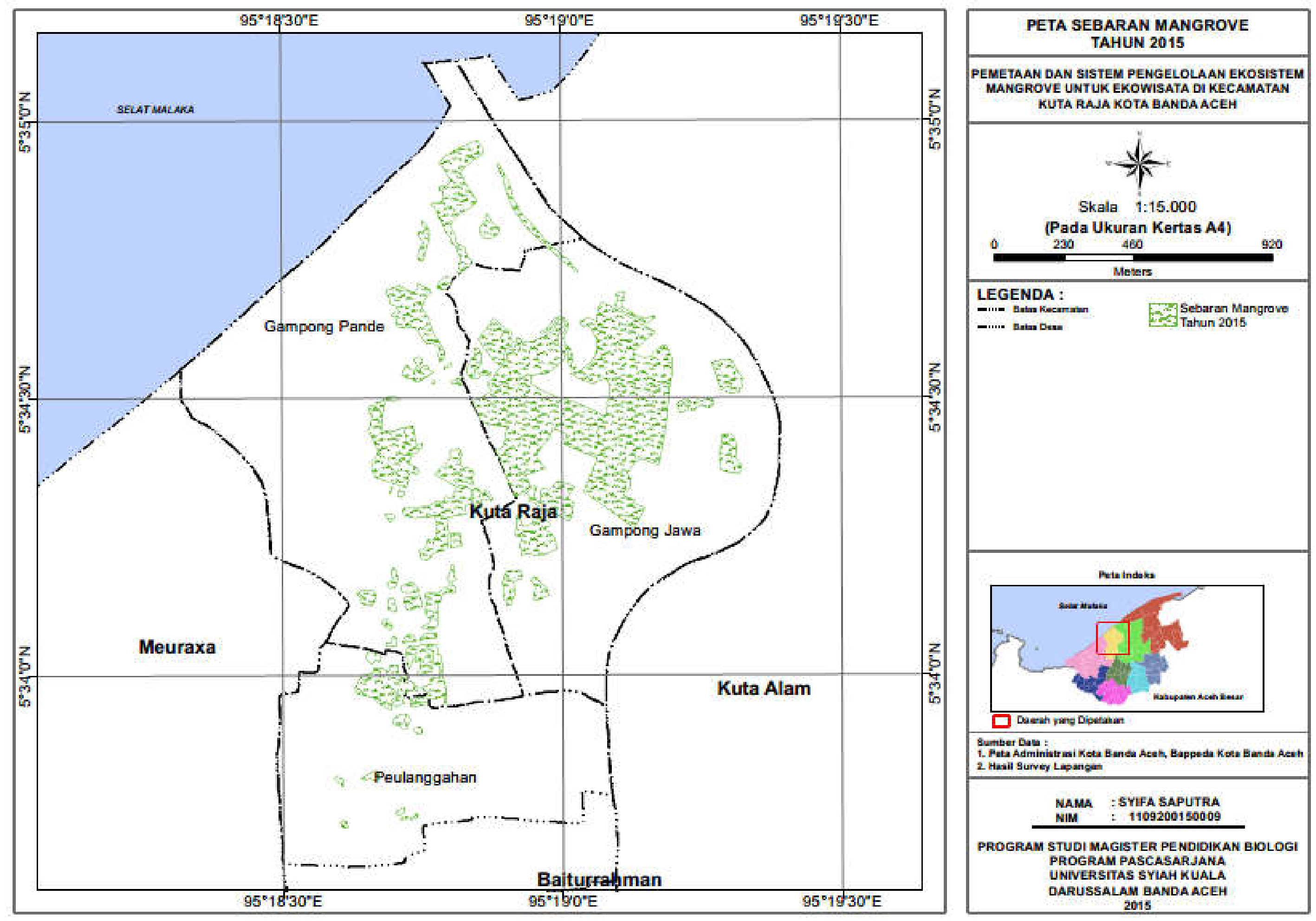


Tabel 4.1. Jenis Mangrove yang terdapat di lokasi penelitian sebelum tsunami 2004 dan sesudah tsunami 2015

\begin{tabular}{llcc}
\hline \multirow{2}{*}{ No } & \multicolumn{2}{c}{ Jenis Mangrove } & \multicolumn{2}{c}{ Keterangan } \\
& & Sebelum tsunami & Sesudah tsunami \\
\hline 1. & Acrostichum aureum & - & $\checkmark$ \\
2. Acrostichum speciosum & - & $\checkmark$ \\
3. Aegiceras floridum & - & $\checkmark$ \\
4. Amyema anisomeres & - & $\checkmark$ \\
5. Avicennia alba & $\checkmark$ & $\checkmark$ \\
6. Avicennia lanata & $\checkmark$ & $\checkmark$ \\
7. $\quad$ Avicennia marina & $\checkmark$ & $\checkmark$ \\
8. $\quad$ Bruguiera parviflora & - & $\checkmark$ \\
9. Ceriops decandra & - & $\checkmark$ \\
10. Excoearia agallocha & - & $\checkmark$ \\
11. Nypa fruticans & $\checkmark$ & $\checkmark$ \\
12. Rhizophora apiculata & $\checkmark$ & $\checkmark$ \\
13. Rhizophora mucronata & $\checkmark$ & $\checkmark$ \\
14. Rhizophora stylosa & - & $\checkmark$ \\
15. Sonneratia alba & $\checkmark$ & $\checkmark$ \\
16. Sonneratia caseolaris & - & $\checkmark$ \\
17. Sonneratia ovate & - & $\checkmark$ \\
18. Xylocarpus granatum & $\checkmark$ & $\checkmark$ \\
\hline
\end{tabular}

Sumber : Balai Pengelolaan Mangrove Provinsi Aceh.

Ekosistem mangrove yang terdapat di lokasi penelitian sangat spesifik dan khas karena tidak terletak pada pinggir pantai tetapi berada sekitar 300 meter dari garis pantai. Pasca tsunami melanda pesisir Aceh ekosistem mangrove mendapat perhatian serius dari pemerhati lingkungan, sehingga upaya-upaya penanaman kembalipun dilakukan. Dalam menjaga ekosistem mangrove dari kerusakan akibat gelombang tsunami maka diperlukan suatu sistem pengelolaan yang baik sehingga memberikan dampak secara lansung bagi masyarakat dan keberlangsungan ekosistem mangrove. 

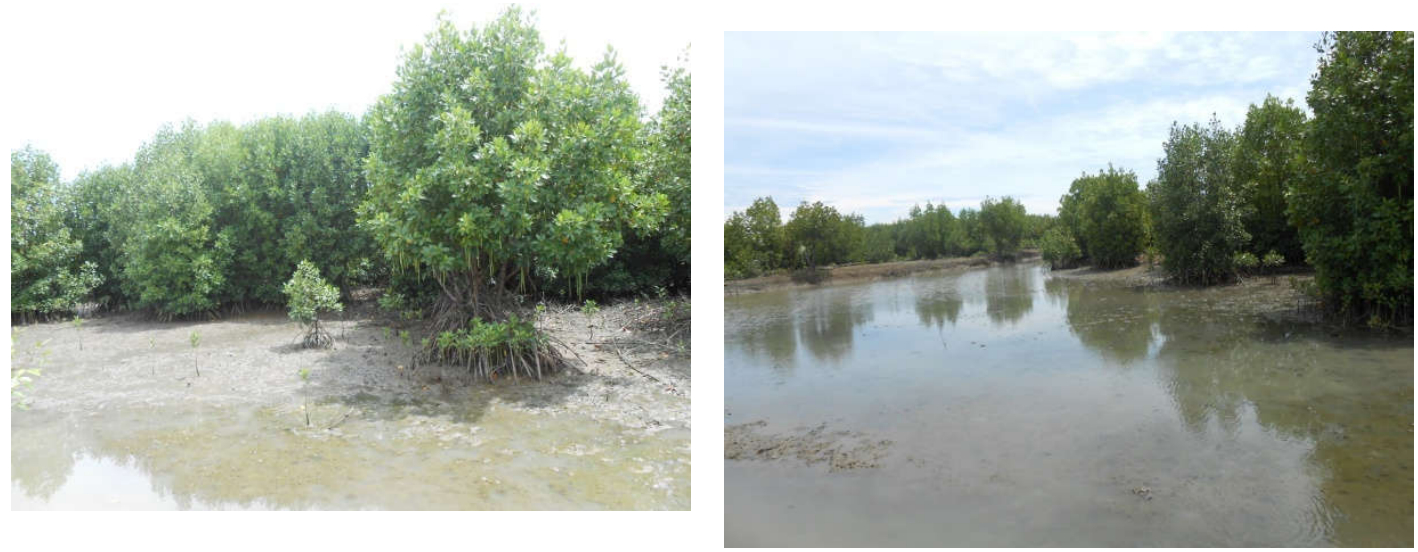

Gambar 4.3 Kondisi mangrove yang terdapat di lokasi penelitian

Berdasarkan gambar 4.3 terlihat bahwa, jenis mangrove yang tumbuh pada daerah penelitian ada 18 jenis yaitu Acrostichum aureum, Acrostichum speciosum, Aegiceras floridum, Amyema anisomeres, Avicennia alba, Avicennia lanata, Avicennia marina, Bruguiera parviflora, Ceriops decandra, Excoearia agallocha, Nypa fruticans, Rhizophora apiculata, Rhizophora mucronata, Rhizophora stylosa, Sonneratia alba, Sonneratia caseolaris, Sonneratia ovata, dan Xylocarpus granatum. Adapun jenis mangrove berdasarkan lokasi penelitian disajikan pada tabel 4.2. 
Tabel 4.2. Jenis Mangrove yang ditemukan di lokasi penelitian

\begin{tabular}{clccc}
\hline NO & \multicolumn{1}{c}{ Species } & $\begin{array}{c}\text { Gampong } \\
\text { Jawa }\end{array}$ & $\begin{array}{c}\text { Gampong } \\
\text { Pande }\end{array}$ & $\begin{array}{c}\text { Gampong } \\
\text { Peulanggahan }\end{array}$ \\
\hline 1 & Acrostichum aureum & $\checkmark$ & $\checkmark$ & - \\
2 & Acrostichum speciosum & - & $\checkmark$ & - \\
3 & Aegiceras floridum & $\checkmark$ & - & - \\
4 & Amyema anisomeres & $\checkmark$ & $\checkmark$ & - \\
5 & Avicennia alba & $\checkmark$ & $\checkmark$ & - \\
6 & Avicennia lanata & $\checkmark$ & $\checkmark$ & - \\
7 & Avicennia marina & - & $\checkmark$ & - \\
8 & Bruguiera parviflora & - & $\checkmark$ & - \\
9 & Ceriops decandra & - & $\checkmark$ & $\checkmark$ \\
10 & Excoearia agallocha & - & $\checkmark$ & $\checkmark$ \\
11 & Nypa fruticans & $\checkmark$ & $\checkmark$ & $\checkmark$ \\
12 & Rhizophora apiculata & $\checkmark$ & $\checkmark$ & $\checkmark$ \\
13 & Rhizophora mucronata & $\checkmark$ & - & - \\
14 & Rhizophora stylosa & $\checkmark$ & - & - \\
15 & Sonneratia alba & $\checkmark$ & - & - \\
16 & Sonneratia caseolaris & $\checkmark$ & - & - \\
17 & Sonneratia ovata & $\checkmark$ & $\checkmark$ & - \\
18 & Xylocarpus granatum & $\checkmark$ & & - \\
\hline Sum & & & - \\
\hline
\end{tabular}

Sumber : pengamatan lapangan.

\subsubsection{Sebaran Mangrove di Lokasi Penelitian}

Berdasarkan pengamatan di lokasi penelitian terdapat ekosistem mangrove, baik yang tumbuh secara alami maupun sengaja ditanam (silvofishery).

Ekosistem mangrove alami mempunyai keragaman jenis dan terdapat di Gampong Jawa, sedangkan silvofishery terdapat di Gampong Pande dan Gampong Peulanggahan serta sebagian juga ada di Gampong Jawa, pada mangrove ini kurang memiliki keragaman jenis hanya terdapat 3 jenis mangrove yaitu Rizhopora mucronata, Rizhopora apiculata dan Ceriops decandra.

Sebaran mangrove yang terdapat di Kecamatan Kuta Raja tahun 2004 sebelum tsunami tumbuh secara alami, luas mangrove di wilayah tersebut adalah 
66,25 ha, yang terbagi kepada 3 (tiga) gampong yaitu Gampong Pande dengan luas mangrove 22,58 ha, Gampong Jawa 39,77 dan Gampong Peulanggahan 3,9 ha.

Sedangkan sebaran mangrove pada tahun 2015 setelah tsunami di Kecamatan Kuta Raja adalah 47,9 ha, luas penyebaran masing-masing gampong di Kecamatan Kuta Raja adalah Gampong Pande dengan luas mangrove 15,16 ha, Gampong Jawa memiliki luas sebaran mangrove 30,36 ha dan Gampong Peulanggahan 2,38 ha.

Dengan melihat penyebaran jenis mangrove (Table 4.1 dan Tabel 4.2) sangat berbeda. Pada tahun 2004 (Table 4.1) hanya terdapat 6 (enam) jenis mangrove yang tumbuh secara alami, sedangkan pada tahun 2015 (Table 4.2) terdapat 18 (delapan belas) jenis mangrove yang sengaja di tanam untuk menjaga kawasan ekosistem mangrove yang sudah rusak di terjang oleh gelombang tsunami tahun 2004 yang lalu.

\subsubsection{Aspek Ekologi Ekosistem Mangrove Wilayah Penelitian}

Secara umum Kecamatan Kuta Raja berada pada ketinggian 0,5 - 5 meter di atas permukaan laut, dengan demikian dari segi geografis Kecamatan Kuta Raja termasuk dalam zona dataran rendah (kurang dari 100 meter di bawah permukaan air laut). Kemiringan lahan di Kecamatan Kuta Raja berada pada kemiringan 0$8 \%$ atau dapat dikatakan bahwa lahan di wilayah ini relatif datar. 


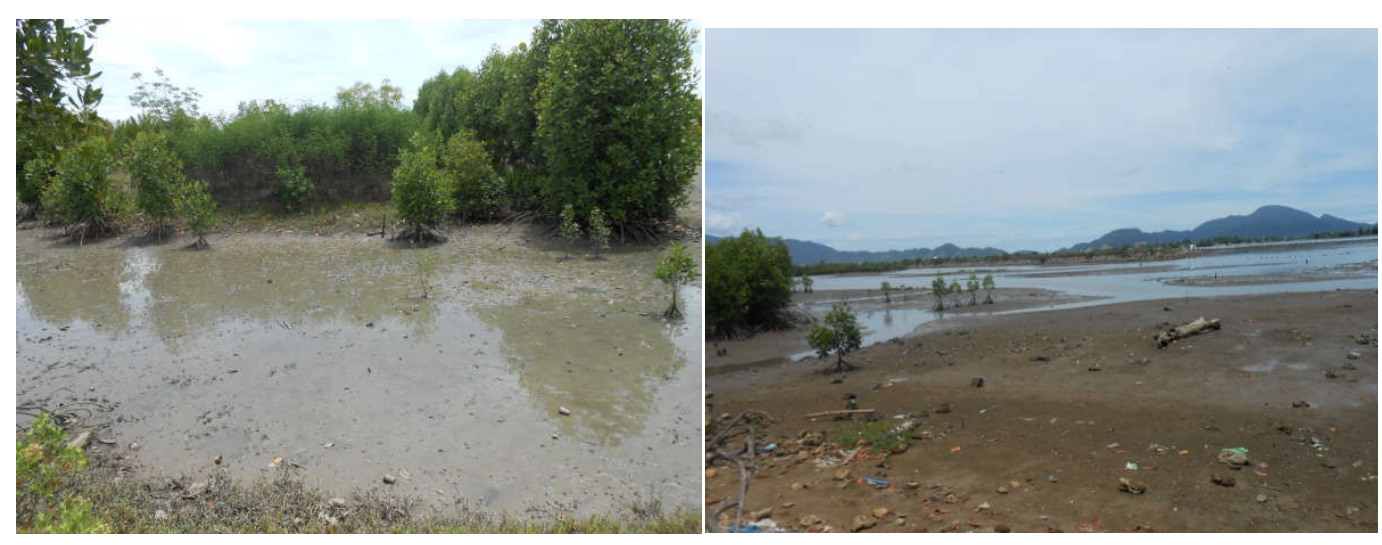

Gambar 4.4 Subtrat tanah yang terdapat di ekosistem mangrove

Berdasarkan pengamatan lapangan (Gambar 4.4), jenis subtratnya berlumpur berpasir, pasokan air berasal dari pasang surut yang terjadi, daerah ini subtratnya selalu di basahi air karena ada pasokan air dari saluran pembuangan limbah warga yang mengalir ke area mangrove dan lebih cepat menerima pasokan air laut , karena memang sudah dibentuk saluran untuk air masuk, air pasang setinggi $70 \mathrm{~cm}$ dan daerah ini sering tergenang sisa dari air hujan. Berdasarkan hasil penelitian Kam (2005), kawasan ini termasuk dalam kategori kandungan salinitas baik sehingga secara keseluruhan tanah di daerah ini cocok untuk pertumbuhan mangrove, sehingga pada muara sungai terjadi proses sendimentasi membentuk tanah yang berlumpur (Sidabutar dan Nurisjah, 2010). Watansen (2002) menyatakan bahwa pantai yang datar memiliki tingkat keanekaragaman ekosistem mangrove yang tinggi dibandingkan dengan pantai yang terjal, karena pada daerah yang datar memiliki ruang yang luas untuk ditumbuhi oleh mangrove sehingga distribusi jenis mangrove meluas dan melebar. 


\subsubsection{Zonasi Hutan Mangrove Wilayah Penelitian}

Ekosistem mangrove umumnya tumbuh pada 4 (empat) zonasi yaitu zona terbuka, zona tengah, zona berair payau dan zona daratan, zonasi sering ditemui dari arah laut ke darat. Zona pertama adalah jalur Avicennia spp yang sering berkelompok dengan Sonneratia sp, kemudian jalur Rhizophora spp, Bruguiera sp dan terakhir Nypa sp. Zonasi dari hutan mangrove mencerminkan tanggapan ekofisiologis tumbuhan mangrove terhadap gradasi lingkungan, zonasi yang terbentuk berupa zonasi yang sederhana (satu zonasi) dan zonasi yang kompleks (beberapa zonasi) tergantung pada kondisi ekosistem mangrove.

Berdasarkan pengamatan (Gambar 4.5), zona yang terdapat di lokasi penelitian hampir sama dengan zona pada umumnya yaitu zona terbuka, zona tengah, zona berair payau dan zona daratan. Zona terbuka di lokasi penelitian yaitu zona yang langsung berhadapan dengan laut adalah gampong Jawa. Zona tengah yaitu gampong Pande dan sebagian gampong Peulanggahan yang lansung berhadapan dengan bantaran sungai dan masih terjadinya pasang surut. Zona tengah terdapat di Gampong Peulanggahan, sebagian wilayah Gampong Peulanggahan masih adanya tambak-tambak warga dan sepanjang tambak tersebut terdapat mangrove yang ditanam (silvofishery). Sedangkan zona berair payau terdapat disebagian Gampong Jawa. Mangrove yang terdapat di zona berair payau ekosistem mangrove tumbuh secara alami dibuktikan dengan tumbuhnya Nypa sp, Avicennia spp. 


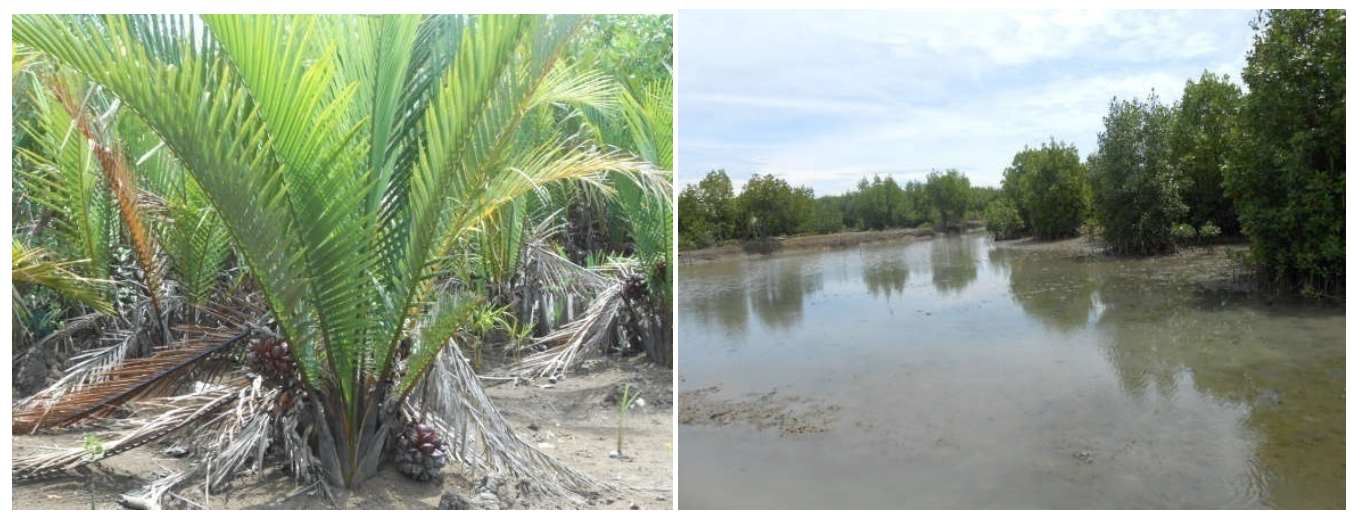

Gambar 4.5 Zonasi hutan mangrove di lokasi penelitian

\subsection{Jenis Biota Wilayah Penelitian}

Ekosistem mangrove merupakan daerah yang sangat unik, yang menghubungkan kehidupan biota daratan dan laut dimana organisme daratan menempati bagian atas sedangkan hewan lautan menempati bagian bawah. Secara biologis, hutan mangrove mempertahankan fungsi dan kekhasan ekosistem pantai, termasuk kehidupan biotanya, seperti pemijahan, tempat mencari makanan, asuhan berbagai jenis ikan, udang dan biota air lainnya, tempat bersarang berbagai jenis burung dan habitat berbagai jenis fauna.

Kebanyakan orang menganggap mangrove sebagai tempat berlumpur dan rawa-rawa becek yang penuh dengan nyamuk, ular, laba-laba dan memberi rasa tidak nyaman. Namun apabila diperhatikan lebih teliti berjalan-jalan di kawasan mangrove merupakan perburuan besar. Pada ekosistem mangrove terdapat berbagai jenis arthrophoda, molusca, burung, reptilia, mamalia dan lain-lain sehingga menarik untuk dikaji.

Kawasan ekosistem mangrove di Kecamatan Kuta Raja memiliki beberapa biota yang berasosiasi di mangrove. Jenis-jenis satwa atau biota yang ditemukan di Kecamatan Kuta Raja yaitu : burung, reptil, ikan, crustacea dan serangga. 


\subsubsection{Burung}

Areal hutan mangrove memiliki peranan yang sangat penting terhadap ketersediaan habitat burung yang hidup dan memanfaatkan kawasan sebagai tempat bermain dan mencari makan. Dalam pengamatan di lokasi penelitian didapatkan 9 (sembilan) jenis.

Tabel 4.3. Jenis burung yang ditemukan dikawasan ekosistem mangrove wilayah penelitian.

\begin{tabular}{clll}
\hline No & \multicolumn{1}{c}{ Spesies } & \multicolumn{1}{c}{ Nama Indonesia } & \multicolumn{1}{c}{ Nama Lokal } \\
\hline 1. & Pycnonotus goiavier & Cerukcuk & Brujuk \\
2. & Egretta alba & Kuntul putih besar & Kuk puteh \\
3. & Egretta garzeta & Kuntul kecil & Kuk babah hitam \\
4. & Passer montanus & Burung Geraja & Tulo breuh \\
5. & Prinia inornata blanfordi & Perenjak padi & Teik-teik \\
6. & Ardeola speciosa & Blekok sawah & - \\
7. & Leptoptilus javanicus & Tongtong & Enggang \\
8. & Nyctocorax nyctocorax & - & - \\
9. & Todirhampus chloris & Cekakak sungai & Keik-keik \\
\hline
\end{tabular}

Sumber : Pengamatan Lapangan.

Berdasarkan tabel 4.3 ditemukan jenis burung Ardeola speciosa, Pycnonotus goiavier, Passer montanus, Leptoptilus javanicus, dan Prinia inornata blanfordi menjadikan mangrove yang ada sebagai tempat beristirahat pada malam hari, mereka mencari makan disekitar lokasi penelitian. Sedangkan Nycticorax nycticorax, Todirhampus chloris, Egretta alba, dan Egretta garzeta berada di area mangrove sepanjang harinya karena lokasi mencari makanannya berada di daerah tambak.

Ardeola speciosa berwarna putih dan coklat ini sering terlihat di sawahsawah, baik diperbukitan maupun di pantai. Sedangkan Nycticorax nycticorax adalah burung air yang mudah dikenali, selain bentuk badannya yang agak besar $(61 \mathrm{~cm})$, burung ini mempunyai warna putih diperut, dengan mahkota hitam 
dikepala dan sayap kelabu. Burung ini mencari makan dimalam hari, bila siang hari suka beristirahat di rimbunan pohon nipah. Nycticorax nycticorax mencari makan di sawah, padang rumput, dan pinggir sungai.

\subsubsection{Reptil}

Hutan mangrove merupakan habitat dari berbagai jenis satwa yang beranekaragam salah satunya adalah reptil. Jenis reptil yang ditemukan pada lokasi penelitian adalah kadal dan biawak. Reptil menjadikan hutan mangrove ini sebagai tempat untuk bertelur, tempat mengasuh anak dan juga menjadi tempat mencari makan. Pengambilan data diperoleh dengan menggunakan metode sensus visual dengan melihat lansung biota disekitar ekosistem mangrove dan diskusi dengan masyarakat setempat.

\subsubsection{Ikan}

Hutan mangrove juga merupakan tempat pemijahan, tempat asuhan dan tempat mencari makan bagi ikan. Hal ini sesuai dengan pernyataan Nybakken (1992) bahwa ikan menjadikan areal mangrove sebagai tempat untuk pemijahan, habitat permanen atau tempat berbiak. Sebagai tempat pemijahan, areal mangrove berperan penting karena menyediakan tempat naungan serta mengurangi tekanan predator, khususnya ikan predator. Jenis ikan yang ditemukan di lokasi disajikan pada Table 4.4 .

Tabel 4.4. Jenis ikan yang terdapat di kawasan ekosistem mangrove wilayah penelitian

\begin{tabular}{clll}
\hline No & \multicolumn{1}{c}{ Spesies } & \multicolumn{1}{c}{ Nama Indonesia } & \multicolumn{1}{c}{ Nama Lokal } \\
\hline 1. & Chanos-chanos & bandeng & muloh \\
2. & Oreochromis mossambicus & Mujair & Mujahet \\
3. & Mugil sp & Balanak & Kadra \\
4. & Periophthalmus sp & tembakul/amphibi & - \\
\hline
\end{tabular}

Sumber : Pengamatan Lapangan. 
Dalam menangkap ikan masyarakat memasang bubu pada saat menjelang air laut mulai surut, sedangkan untuk jenis ikan lainnya biasanya masyarakat menggunakan pancing.

\subsubsection{Crustacea}

Hutan mangrove merupakan habitat yang sangat sesuai untuk crustacean. Ada beberapa jenis crustacea yang ditemukan di lokasi penelitian seperti udang dan kepiting. Kepiting yang ditemukan adalah kepiting biola merah, kepiting batu, kepiting lumpur, dan udang merah.

\subsubsection{Serangga}

Jenis insekta atau serangga yang ditemukan di lokasi penelitian adalah laba-laba, kupu-kupu, semut merah dan Dycondilla. Dycondilla adalah kelompok serangga, dimana jenis serangga ini merupakan spesies yang jarang ditemukan ditempat lain, hanya pada daerah tertentu. Pengambilan data diperoleh dengan menggugunakan metode sensus visual dengan melihat lansung biota disekitar.

\subsection{Sistem Pengelolaan Ekosistem Mangrove}

Kecamatan Kuta Raja merupakan salah satu kawasan yang mempunyai kawasan ekosistem mangrove yang sebagian besar terdapat di gampong Peulanggahan, gampong Pande dan gampong Jawa. Sebaran hutan mangrove mencakup sebagian luas kota Banda Aceh. Keberadaan hutan mangrove menjadi daya tarik tersendiri bagi keberlangsungan hidup jenis-jenis biota ekosistem mangrove dan dapat dijadikan sebagai objek ekowisata yang bersifat komersil. 
Sebelum tsunami tahun 2004 hutan mangrove di Kuta Raja sangat luas mencapai 66,25 Ha, sehingga hutan mangrove yang ada di Kuta Raja masih terjaga kealamiannya oleh karenanya pengelolaan ekosistem mangrove diperlukan. Setelah tsunami banyak ekosistem mangrove yang tidak terselamatkan, keberadaan ekosistem hutan mangrove dalam tahap kritis. Pada tahun 2015 data menunjukkan keberadaan hutan mangrove sudah sangat baik. Banyak aktivitis lingkungan tergerak untuk memperhatikan keberadaan mangrove baik di Kuta Raja sendiri maupun di seputaran kota Banda Aceh, luas hutan sampai saat ini adalah sekitar 47,9 Ha. Perhatian aktivis lingkungan terhadap mangrove akan menjadi daya pikir tersendiri dalam proses restorasi dan konservasi mangrove di Kuta Raja.

Untuk itu perlu di beri pemahaman bahwa keberadaan hutan sangat berpotensi untuk dikelola dan dikembangkan dalam meningkatkan kesejahteraan masyarakat karena memiliki keunikan dan kekhasan tersendiri seperti bentuk akarnya serta berbagai jenis fauna yang berasosiasi dengan ekosistem mangrove seperti burung, reptil, ikan, crustacea, serangga dan berbagai jenis flora dan fauna lainnya, sehingga potensi ekosistem mangrove di Kecamatan Kuta Raja sangat baik, untuk pengelolaan sebagai daerah tujuan ekowisata alternative, apalagi di kawasan ekosistem mangrove tersebut terdapat situs makam raja-raja kesultanan Aceh dan juga menarik dikelola sebagai daerah ekowisata berbasis historis. Namun pada dasarnya keberadaan ekosistem hutan mangrove ini jarang mendapat perhatian karena melihat ekosistem ini hanya seperti semak belukar yang tidak terawat dan tidak berfungsi. Selain itu juga terdapat keterbatasan pemahaman akan nilai dan fungsi ekosistem hutan mangrove. Sebagian masyarakat 
mengetahui mangrove hanya berfungsi sebagai ekosistem yang dapat menunjang produktivitas hasil budaya tanpa mengetahui fungsi lain dari ekosistem mangrove.

Pengelolaan kawasan hutan mangrove di Kuta Raja belum terkelola dengan baik. Hal ini berdasarkan diskusi dengan masyarakat setempat dan tinjauan lansung ke lokasi penelitian. Masyarakat yang dilibatkan untuk wawancara terdiri dari 10 orang yang merupakan penduduk yang menetap di wilayah mangrove dari masing-masing gampong dan menunjukkan bahwa pemahaman akan manfaat pentingnya keberadaan mangrove terhadap lingkungan sudah memadai.

Menurut masyarakat keberadaan mangrove di kawasan tersebut dapat memberikan manfaat, diantaranya adalah :

1. Dapat meminimalisir bencana alam seperti gelombang angin dan gelombang tsunami.

2. Sebagai tempat ikan dan biota lainnya hidup serta dapat dimanfaatkan untuk konsumsi, seperti ikan dan kepiting.

3. Daun mangrove yang sudah tua dapat dijadikan sebagai pakan kambing.

Oleh sebab itu, harapan masyarakat setempat terhadap pemerintah dan stakeholders lainnya adalah :

1. Perlunya sosialisasi yang lebih efektif dari pemerintah tentang pengelolaan ekosistem mangrove sehingga dapat memberikan manfaat dan keuntungan bagi masyarakat setempat.

2. Keterlibatan masyarakat dalam pengelolaan hutan mangrove perlu ditingkatkan. 
Menurut Anonim (2013), pengelolaan ekosistem mangrove berbasis masyarakat dilaksanakan untuk melestarikan nilai penting ekologi, sosial ekonomi, dan sosial budaya, guna meningkatkan pendapatan masyarakat dan mendukung pembangunan yang berkelanjutan.

\subsubsection{Teknik Silvofishery}

Silvofishery merupakan gabungan dari dua kata yaitu silvi atau silvo yang berarti hutan dan fishery yang berarti perikanan. Silvofishery adalah salah satu konsep kuno dalam pengelolaan sumberdaya pesisir yang mengintegrasikan konservasi hutan mangrove dengan budidaya air payau (Gambar 4.6). Sehingga silvofishery dapat diterjemahkan sebagai perpaduan antara tanaman mangrove dengan budidaya perikanan.

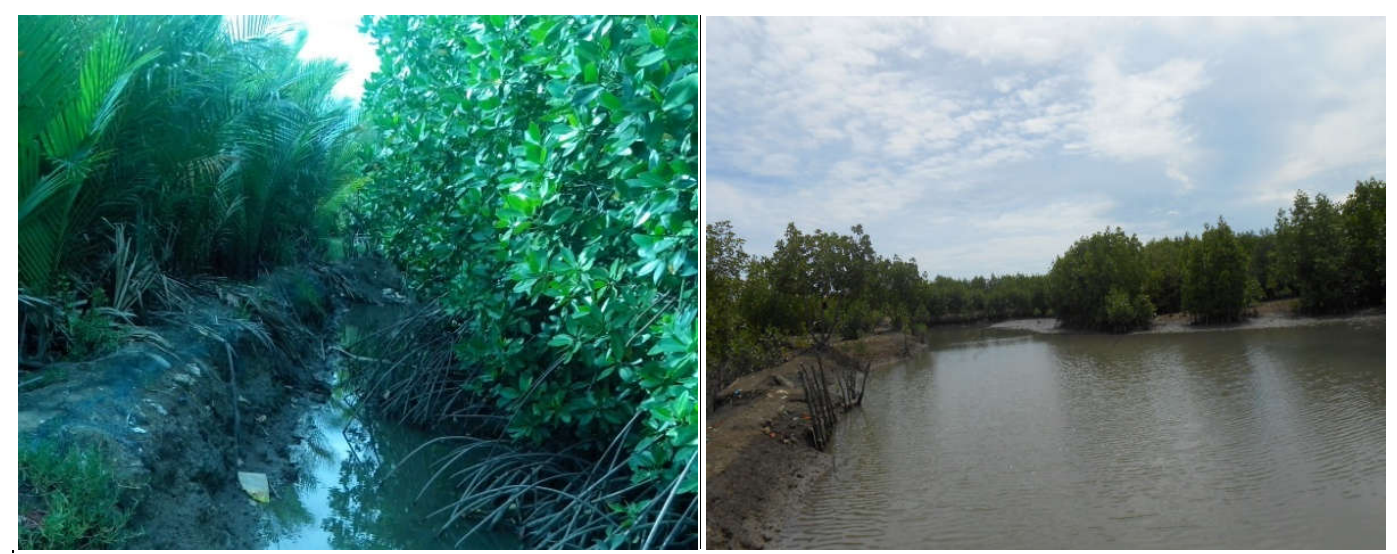

Gambar 4.6 Teknik silvofishery yang terdapat di lokasi penelitian

Tambak tradisional yang telah dikembangkan selama berabad-abad silam tidak terlalu menjadi hal yang merisaukan dari segi lingkungan karena menggunakan vegetasi mangrove sebagai bagian dari sistem. Hal ini merupakan suatu bentuk kearifan lokal yang patut dijadikan orientasi dalam pelestarian hutan mangrove. 
Upaya dalam pengelolaan ekosistem hutan mangrove dapat dilakukan melalui teknik silvofishery. Silvofishery merupakan teknik pertambakan ikan dan udang yang dikombinasikan dengan vegetasi hutan mangrove. Usaha ini dilakukan dalam meningkatkan kesejahteraan masyarakat sekitar hutan dan memelihara ekosistem hutan mangrove sehngga terjaga kelangsungan hidupnya.

Berdasarkan pengamatan di lokasi penelitian ada dua model teknik silvofishery (Gambar 4.7) yaitu model empang parit dan model komplangan (mangrove yang berselang seling dengan tambak). Model empang parit menyajikan tingkatan yang lebih besar dalam penanaman mangrove atau mempertahankan keberadaan mangrove dalam area tambak. Sedangkan model komplangan/berselang seling adalah merekomendasikan untuk mempertahankan mangrove dengan rasio maksimum yang sama yaitu, tiap $2 \mathrm{Ha}$ tambak harus dipertahankan 8 Ha mangrove disekeliling tambak tersebut.

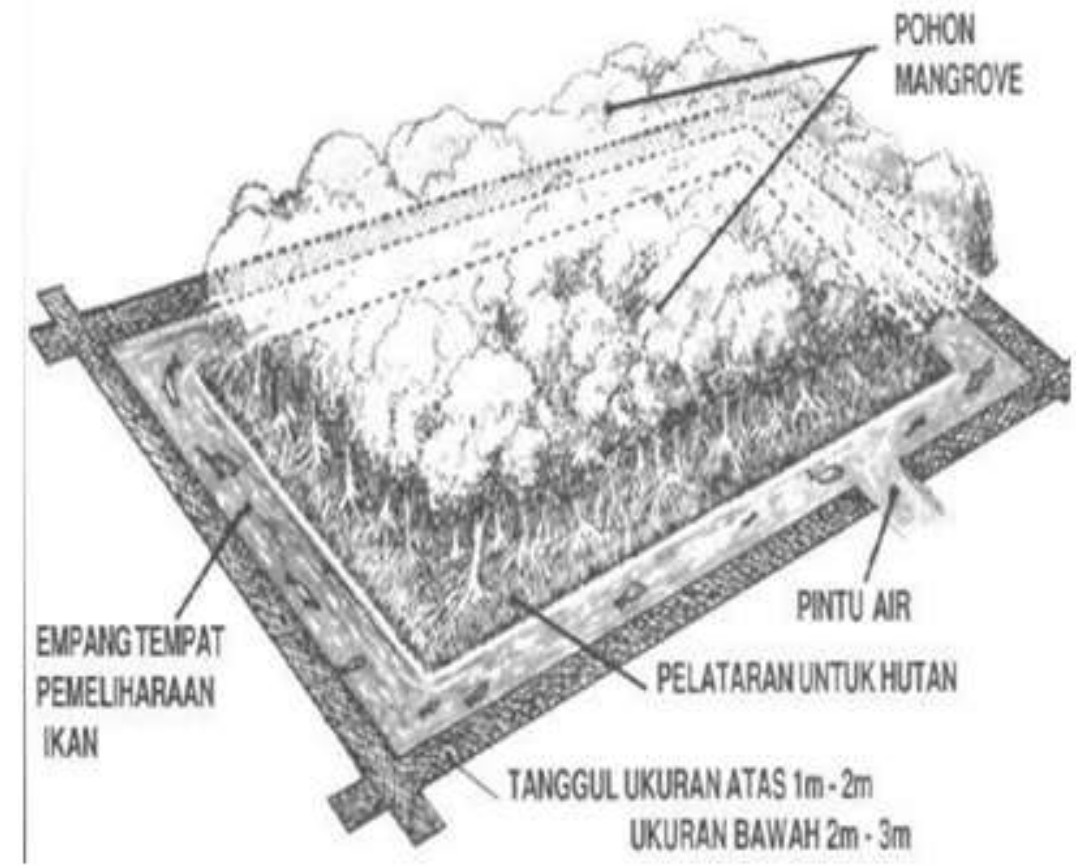




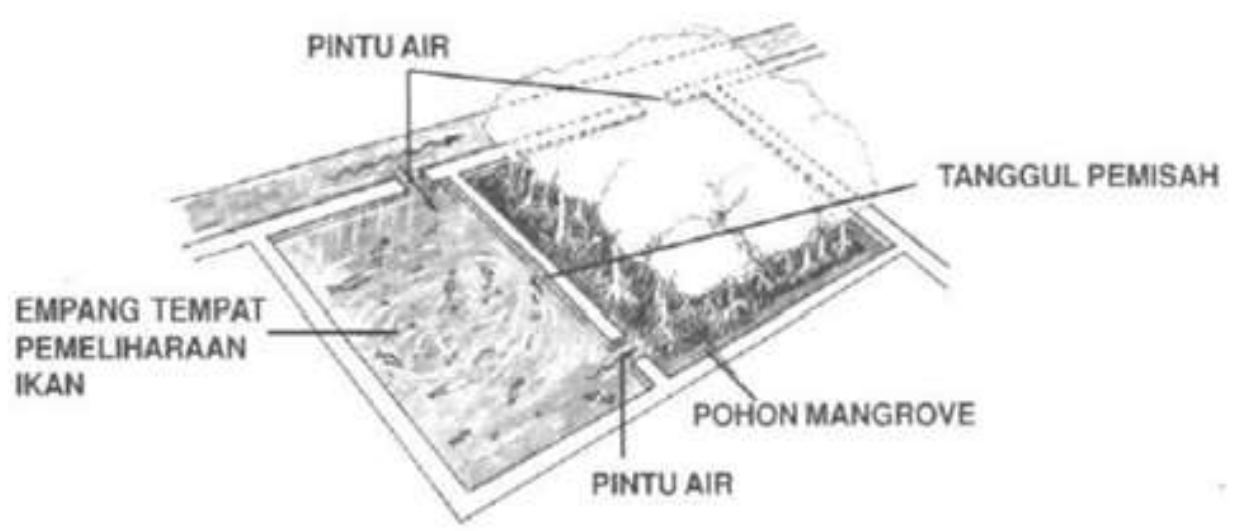

Gambar 4.7 Model teknik silvofishery di lokasi penelitian (Ardhana, 2015).

Menurut Triyanto, dkk. (2012), Budidaya sistem silvofishery di dalam area mangrove memungkinkan adanya budidaya perikanan tanpa perlu merubah area mangrove. Alternatif pengelolaan demikian diharapkan dapat meningkatkan nilai kesejahteraan ekonomi masyarakat tanpa mengancam fungsi ekologi mangrove (Triyanto, dkk. 2012). Ekosistem mangrove harus dikelola berdasarkan pada paradigma ekologi yang meliputi prinsip-prinsip interdepedensi antar unsur ekosistem, sifat siklus dari proses ekologis, fleksibilitas, diversitas dan koevolusi dari organisme beserta lingkungannya dalam suatu unit fisik Daerah Aliran Sungai (DAS) dan merupakan bagian integral dari program Pengelolaan Wilayah Pesisir dan Lautan Terpadu (PWPLT) (Kusmana, 2009).

\subsubsection{Ekowisata Mangrove}

Berdasarkan wawancara dengan masyarakat kawasan mangrove Kuta Raja, Ekowisata mangrove yang berada di kawasan tersebut belum dilakukan upaya pengelolaan dengan baik, selama ini ekosistem mangrove hanya ditanam sebagai wujud peduli terhadap lingkungan sekitar. Akan tetapi belum ada upaya penataan mangrove secara khusus, baik oleh pemerintah daerah maupun 
stakeholders lainnya. Menurut informasi dari masyarakat setempat, kawasan hutan mangrove sering dilakukan upaya penanaman kembali oleh mahasiswa dan atau aktivis lingkungan. Berdasarkan pengamatan lapangan banyak bibit-bibit mangrove yang ditanam dekat dengan tambak warga.

Hutan mangrove tersebar di beberapa daerah di Indonesia, contoh salah satunya ada di kota Surabaya, yang dikenal dengan nama Ekowisata Mangrove Wonorejo (Gambar 4.8). Hal itu menjadi kebanggaan tersendiri bagi warga Surabaya sebab kota Pahlawan ini mampu menyimpan potensi wisata penyelamat lingkungan. Kawasan wisata ini dikembangkan sedemikian rupa untuk memanfaatkan waduk sehingga bisa mengendalikan banjir. Keberadaan hutan mangrove ini pun menjadi habitat bagi berbagai jenis burung termasuk burung migran dan burung yang dilindungi seperti Bubut Jawa, Raja Udang, Kuntul, dan lain sebagainya. Pengunjung juga dimanjakan dengan keindahan pemandangan pantai serta eksotisnya flora dan fauna di kawasan itu. Panorama tersebut dapat dilihat secara langsung di joglo yang berada di tengah pantai.
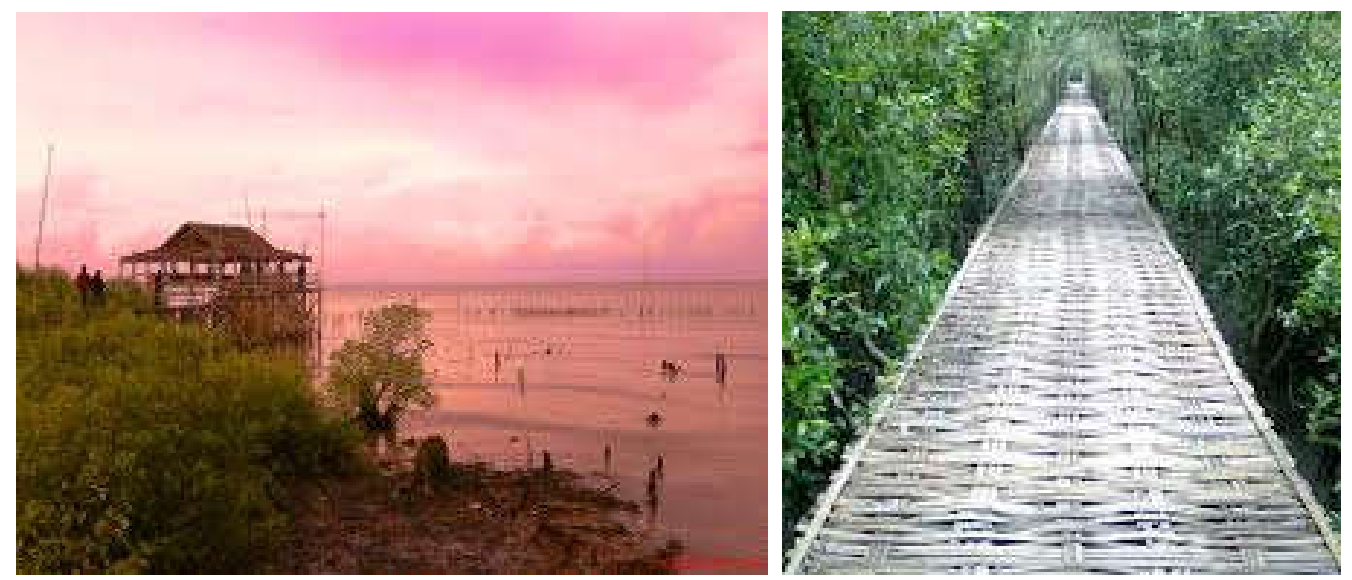

Gambar 4.8 salah satu kondisi ekowisata mangrove di Wonorejo

Ekosistem mangrove di Kuta Raja memiliki potensi yang sangat unik yaitu terdapat makam kerajaan sultan-sultan Aceh di kawasan mangrove. Keberadaan 
makam-makam ini mempunyai nilai lebih, baik dari segi pendidikan, historis maupun dari segi ekonomi. Nilai pendidikan yang dimaksud pengunjung dapat mempelajari lebih lanjut tentang ekosistem mangrove, Ekologi hutan mangrove dan biologi pesisir dan laut, sedangkan dari nilai historis pengunjung dapat mempelajari letak kejayaan islam melalui situs makam raja-raja Kesultanan Aceh (Gambar 4.9), sehingga ekonomi masyarakat dapat bertambah. oleh sebab itu, pemerintah bersama masyarakat harus mengelola mangrove dengan baik, sebagai bentuk respon dalam melestarikan alam dan lingkungan sekitar.

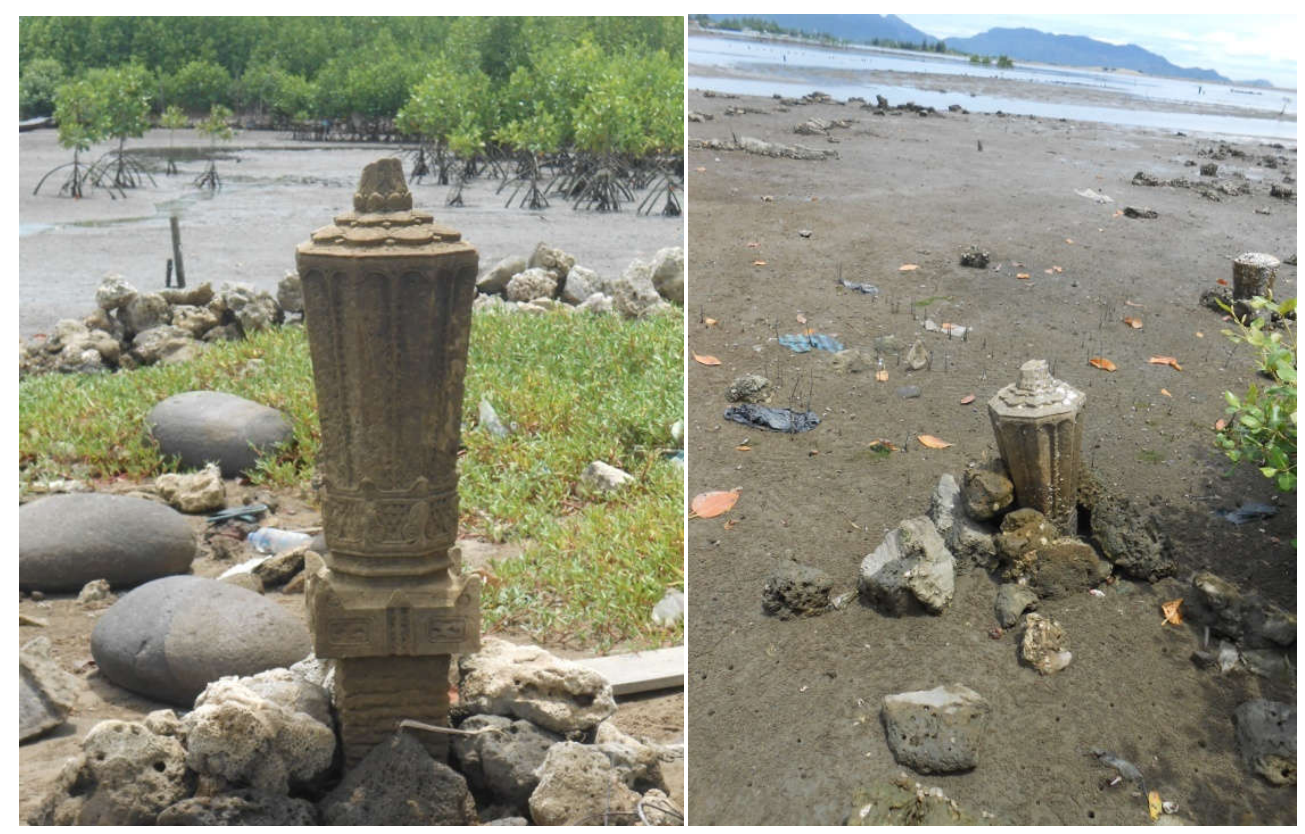

Gambar 4.9 Salah satu makam raja-raja kesultanan Aceh yang terdapat di kawasan mangrove 


\section{BAB V}

\section{SIMPULAN DAN SARAN}

\subsection{Simpulan}

Berdasarkan hasil penelitian dan pembahasan dapat diambil kesimpulan bahwa :

1. Ekosistem mangrove yang terdapat di Kecamatan Kuta Raja Kota Banda Aceh sebelum tsunami memiliki luas 66,25 Ha, sedangkan luas mangrove setelah tsunami tahun 2015 adalah 47, 9 Ha.

2. Dalam kawasan tersebut ditemukan 18 jenis mangrove, sedangkan jenis biota ekosistem mangrove dibatasi pada burung 9 (Sembilan) jenis, reptile 2 (dua) jenis, ikan 4 (empat) jenis, crustacea 4 (empat) jenis dan serangga 4 (empat) jenis.

3. Pemetaan dengan software SIG dan sistim pengelolaan ekosistem mangrove dapat dilakukan dengan model empang parit dan model komplangan (silvofishery) serta melibatkan masyarakat setempat untuk menjadikan tatanan pengelolaan ekosistem mangrove lebih menarik untuk ekowisata.

\subsection{Saran}

1. Perlu perhatian dari pihak pemerintah daerah yang lebih lanjut dan berkesinambungan dalam mendukung terciptanya kawasan konservasi dan kawasan ekowisata di Kecamatan Kuta Raja. 
2. Perlunya pelibatan masyarakat lebih aktif dalam berbagai perencanaan pembangunan daerah khususnya dalam pengelolaan ekosistem mangrove untuk tercapai tata kelola RTRW yang baik. 


\section{DAFTAR PUSTAKA}

Anonim. 2003. Strategi Nasional Pengelolaan Ekosistem Mangrove, Edisi Kedua. Jakarta: Departemen Kehutanan Indonesia.

Anonim. 2013. Strategi Nasional : Pengelolaan Ekosistem Mangrove Indonesia. Jakarta: Menteri Kehutanan Republik Indonesia.

Anwar, J., Sengli, J., Damanik, H.N dan Whitten, A.S. 1984. Ekologi Hutan Sumatra. Yogyakarta: Gajah Mada University Press.

Ardhana, A. 2015. Silvofishery Sebagai Pilihan strategi Rehabilitasi Mangrove. (Online), (http://foreibanjarbaru.or.id, diakses 09 Juli 2015)

Arief, A.M.P. 2003. Hutan Mangrove Fungsi dan Manfaatnya. Yogyakarta: Kanisius.

Aswita, D. 2014. Pemetaan Dan Evaluasi Ekowisata Bahari Di Pantai Teupin Layee Iboih Kota sabang. Unpublished Tesis. Program Pascasarjana Universitas Syiah Kuala. Banda Aceh.

Bengen, D.G. 2001. Pedoman Teknis Pengenalan dan Pengelolaan Ekosistem Mangrove. Bogor, Indonesia: Pusat Kajian Sumberdaya Pesisir dan Lautan - Institut Pertanian Bogor.

Bengen, D.G. 2004. Pedoman Teknis Pengenalan dan Pengelolaan Ekosistem Mangrove. Bogor: PKSPL-IPB,

Bengen, G.D. 2000. Pedoman Teknis Pengenalan dan Pengelolaan Ekosistem Biologi Laut. Jakarta: Djambatan.

Chandar, P.R. dan Karuppasamy, S. 2012. Marine Fishery Information System and Aquaculture Site Selection Using Remote Sensing and GIS. International Journal Of Advanced Remote Sensing and GIS. (Online), jilid 1, no. 1 (www.technical.cloud-jurnals.com, diakses 25 Oktober 2014).

Dahuri, R., Ginting, S.R.P., Rais, J Sitepu J.G. 2001. Pengelolaan Sumber Daya Wilayah Pesisir dan Lautan Secara Terpadu. Bogor: Pradnya Paramita.

Dahuri, R., Ginting, S.R.P., Rais, J dan Sitepu, J.G. 1996. Pengelolaan Sumberdaya Wilayah Pesisir dan Lautan Secara Terpadu. Jakarta: PT. Paradyna Paramitha,

Eddy, S dan Rahim, E.S. 2013. Pengelolaan Ekosistem Hutan Mangrove Berbasis Lingkungan. (Online), (http://syaifuleddy13.blogspot.com, diakses 05 November 2014). 
Fandeli, C. 2002. Perencanaan Kepariwisataan alam. Yogyakarta: Fakultas Kehutanan Universitas Gajah Mada

Harsoyo. 1997. Pembinaan Masyarakat Desa Hutan. Jakarta: Departemen Kehutanan RI.

Hayati, S. 2010. Partisipasi Masyarakat Dalam Pengembangan Ekowisata di Pangandaran - Jawa Barat. Jurnal Forum Geografi. (Online), jilid 24, no. 1 (www.publikasiilmiah.ums.ac.id, diakses 15 Oktober 2014).

Hutabarat, S dan Evans, S.M. 1986. Pengantar Oseanografi. Jakarta: Universitas Indonesia Press,.

Imran, N.A. 2003. Sistem Pengelolaan Ekosistem Mangrove Di wilayah Pesisir Dan Kepulauan. Makalah. Program Studi Pengelolaan Lingkungan Hidup. Program Pascasarjana Universitas Hasanuddin. Makassar.

Indarto. 2013. Sistem Informasi Geografis. Yogyakarta: Graha Ilmu.

Kam, R. 2005. Evaluasi Kualitas Lahan dan arahan Konservasi Pada Kawasan Pantai Banda Aceh Pasca Tsunami. Tesis. Program Pascasarjana Universitas Syiah Kuala. Banda Aceh.

Kasim, M. 2006. Kawasan Mangrove dan Konsep Ecotourism. (Online), (www.ecoutorisem.org, diakses tanggal 26 November 2014)

Khazali, M. 2005. Panduan Teknis Penanaman Mangrove Bersama Masyarakat. Westlands International-Indonesia Programme. Bogor.

Kusmana, C. 2009. Pengelolaan Sistem Mangrove Secara Terpadu. Workshop Pengelolaan Ekosistem Mangrove di Jawa Barat. (Online), (diakses 21 Oktober 2014).

Manongga, D., Papilaya, S dan Pandie, S. 2009. Sistem Informasi Geografis Untuk Perjalanan Wisata Di Kota Semarang. Jurnal Informatika. (Online), jilid 10, no. 1 (www.academia.edu, diakses 21 Oktober 2014).

Mawardi, I. 2006. Pengembangan Ekowisata Sebagai Strategi Pelestarian Hutan Magrove : Studi Kasus Hutan Mangrove di Pantai Utara Kabupaten Indramayu. Jurnal Teknologi Lingkungan. (Online), jilid 7, no. 3 (http://opac.geotek.lipi.go.id, diakses 28 Oktober 2014).

Nontji, A. 2002. Laut Nusantara. Jakarta: Djambatan.

Nugraha, D.W. 2012. Perencanaan Sistem Informasi Geografis Menggunakan peta Digital. Jurnal Ilmiah Foristek. (Online), jilid 2, no. 1 (www.protalgaruda.org, diakses 20 Oktober 2014)

Nybakken, J.W. 1992. Biologi Laut. Suatu Pendekatan Ekologis. Jakarta: PT. Gramedia. 
Odum, W.E dan Heal, E.J. 1972. Trophic Analysis of an Estuarine Mangrove Community. New York: Academic Press.

Onrizal. 2002. Evaluasi Kerusakan Kawasan Mangrove Dan Alternative Rehabilitasinya Di Jawa Barat Dan Banten. Fakultas Pertanian Program Ilmu Kehutanan Universitas Sumatera Utara. Medan. (Online), (www.repository.usu.ac.id, diakses 20 Desember 2014).

Qanun Kota Banda Aceh Nomor 4. 2009. Rencana Tata Ruang Wilayah Kota Banda Aceh Tahun 2009-2029. (Online). (www.bandaacehkota.go.id, diakses 30 Juli 2015).

Rahmawati. 2006. Upaya Pelestarian Mangrove Berdasarkan Pendekatan Masyarakat. Makalah. Fakultas Pertanian Universitas Sumatera Utara, Medan. (Online), (repository.usu.ac.id/bitstream, diakses 16 Januari 2015).

Raymond, G.P. 2010. Pengelolaan Hutan Mangrove Berbasis Masyarakat Di Kecamatan Gending, Probolinggo. Jurnal Agritek. (Online), jilid 18, no. 2 (www.ppsub.ub.ac.id, diakses 21 Oktober 2014).

Romimohtarto, K dan Juwana, S. 1999. Biologi Laut. Pusat Penelitian dan Pengembangan Oseanografi. Jakarta: LIPI.

Romimohtarto, K dan Juwana, S. 2001. Biologi Laut, Ilmu Pengetahuan Tentang Biologi Laut. Jakarta: Djambatan.

Salam, A dan Rachman, A. 1994. Peran Biologi umum dalam Bidang Ilmu Kelautan Untuk Perguruan Tinggi Negeri Kawasan Timur Indonesia. Makalah, Tidak Dipublikasi. Universitas Hasanuddin. Makassar.

Santoso, N. 2000. Pola Pengawasan Ekosistem Mangrove. Makalah disampaikan pada Lokakarya Nasional Pengembangan Sistem Pengawasan Ekosistem Laut Tahun 2000. Jakarta.

Santoso, N. dan Arifin, H.W. 1998. Rehabilitasi Ekosistem Mangrove pada Jalur Hijau di Indonesia. Lembaga Pengkajian dan Pengembangan Mangrove (LPP Mangrove). Jakarta: Indonesia.

Sekartjakrarini, S. 2004. Ekowisata Batasan dan Pengertian : Dalam Seri Ekowisata. Jakarta: IdeA.

Sidabutar, N.V dan Nurisjah. 2010. Prencanaan Hutan Kota Rekreasi Mangrove Di Wilayah Pesisir Kecamatan Kuta Raja, Kota Banda Aceh, Propinsi NAD. Jurnal Lanskap Indonesia, 2(2): 93-99

Subadra, I.N. 2008. Ekowisata sebagai Wahana Pelestarian Alam. Bali. (Online), (http//Bali Tourism Watch Ekowisata sebagai Wahana Pelestarian Alam « Welcome to Bali Tourism Watch.htm, diakses 29 Oktober 2014). 
Supriharyono. 2000. Pelestarian dan Pengelolaan Sumber Daya Alam di Wilayah Pesisir Tropis. Jakarta: PT Gramedia Pustaka Utama.

Suriani, N.E dan Nurdin, M. 2011. Pemetaan Potensi Ekowisata di Taman Nasional Baluran. Jurnal Kepariwisataan Unair, (Online), 24(3), (www.journal.unair.ac.id. diakses : 20 November 2014).

Triyanto., Wijaya, N. I., Widiyanto, T., Yuniarti, I., Setiawan, F dan Lestari, F.S. 2012. Pengembangan Silvofishery Kepiting Bakau (Scylla serrata) dalam Pemanfaatan Kawasan Magrove Di kabupaten Berau, Kalimantan Timur. Prosiding Seminar Nasional Limnologi VI. (Online), (diakses 16 Januari 2015).

Waas. H.J.D dan Nababan, B. 2010. Pemetaan Dan Analisis Index Vegetasi Mangrove Di Pulau Saparua, Maluku Tengah. E-Jurnal Ilmu dan Teknologi Kelautan. (Online), 2(1) : 50-58, Juni. (http://repository.ipb.ac.id. diakses 21 Oktober 2014).

Watansen, A. 2002. Kajian Potensi Sumberdaya Hutan Mangrove di Desa Talise Kabupaten Minahasa, Sulawesi Utara. (Online), (http://library.usu.ac.id, diakses tanggal 29 Januari 2015).

Zalukhu, S. 2009. Ekowisata: Panduan Dasar Pelaksanaan. Dinas Pariwisata dan Kebudayaan Kabupaten Nias. (Online), (http://id.scribd.com diakses 25 November 2014). 
Lampiran 1. Quisioner Wawancara

Judul : Pemetaan dan Sistem Pengelolaan Ekosistem Mangrove Untuk Ekowisata Di Kecamatan Kuta Raja Kota Banda Aceh

\section{Biodata Responden}

Nama

Alamat

Umur

Jenis Kelamin

Pendidikan Terakhir :

\section{Pertanyaan Wawancara}

1. Bisa diceritakan sedikit bagaimana pandangan masyarakat Mengenai kawasan hutan mangrove yang ada di daerah sini ?

2. Bagaimana pengaruh kawasan hutan mangrove bagi masyarakat di daerah ini?

3. Bisa diceritakan sedikit mengenai bagaimana bentuk pengelolaan terhadap kawasan hutan mangrove, mungkin sebelum terjadinya peristiwa gempa bumi dan tsunami ?

4. Lalu bagaimana dengan pengelolaan kawasan hutan mangrove setelah terjadinya gempa dan tsunami ?

5. Selama ini siapa dan bagaimana program atau kegiatan yang dilakukan untuk pengelolaan kawasan hutan mangrove? 
6. Bagaimana persepsi Bapak/Ibu terhadap jenis kegiatan dan manfaat pengelolaan kawasan hutan mangrove yang dilaksanakan?

7. Apakah ada lembaga yang dibentuk khusus untuk melakukan pengelolaan hutan mangrove?

8. Bagaimana bentuk keterlibatan masyarakat atau lembaga masyarakat dalam kegiatan pengelolaan kawasan hutan mangrove?

9. Dalam kegiatan-kegiatan apa saja masyarakat ikut dalam program pengelolaan kawasan hutan mangrove?

10. Bisa diceritakan bagaimana proses penanaman dan pemeliharaan hutan mangrove? 
Lampiran 2. Jenis burung yang terdapat di lokasi penelitian

1.

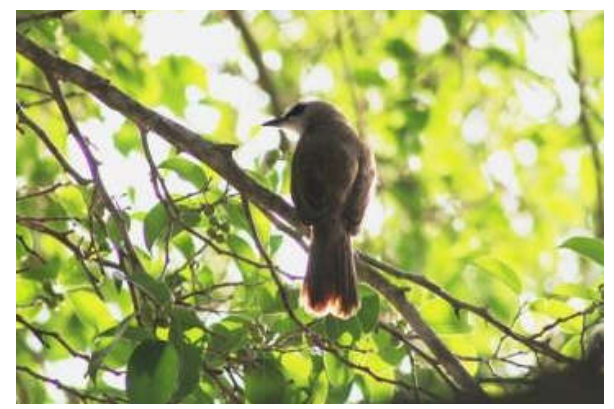

http://ciblekkita.blogspot.com

2.

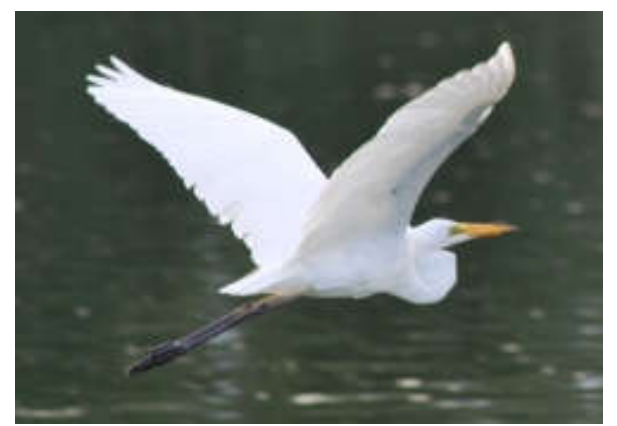

http://nimadesriandani.wordpress.com

3.

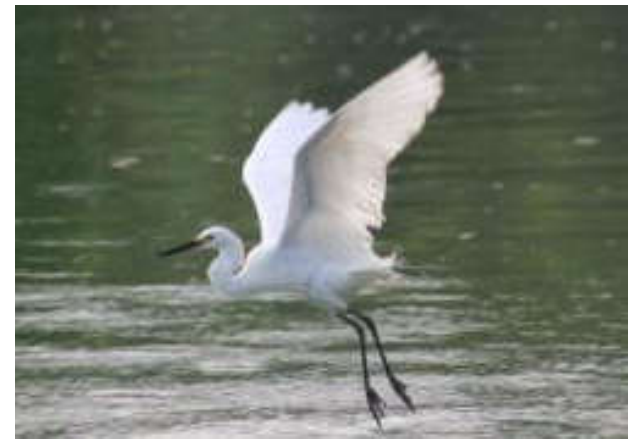

https://nimadesriandani.wordpress.com

4.

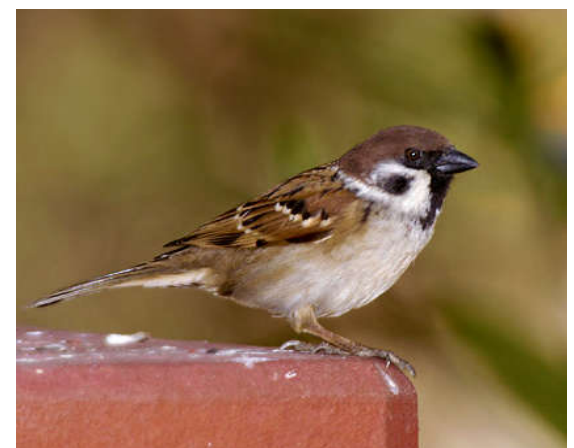

http://ciblekkita.blogspot.com
Burung Cerukcuk Merbah (Pycnonotus goiavier)

Burung Kuntul Putih Besar (Egretta alba)

\section{Burung Kuntul Kecil}

(Egretta garzeta)

\author{
Burung Gereja \\ ( Passer montanus)
}


5.

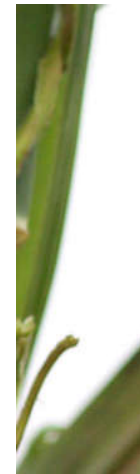

http://ciblekkita.blogspot.com

6.

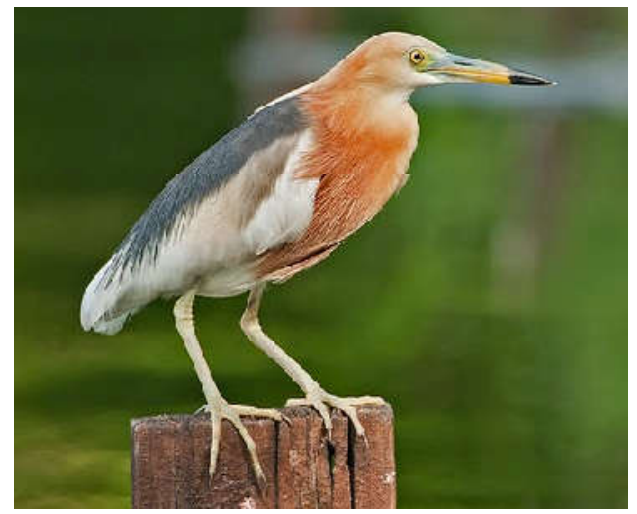

http://mangrovemagz.com/

7.

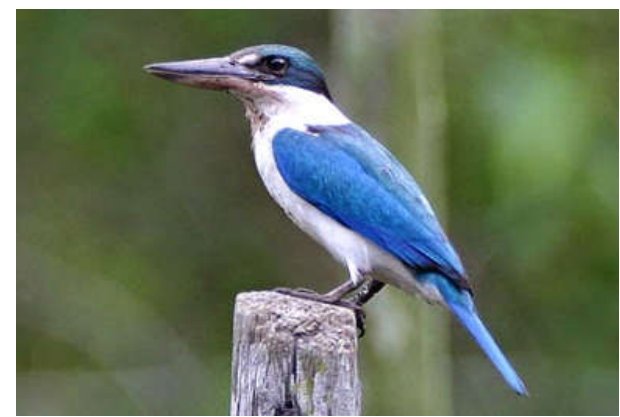

http://mangrovemagz.com

8.

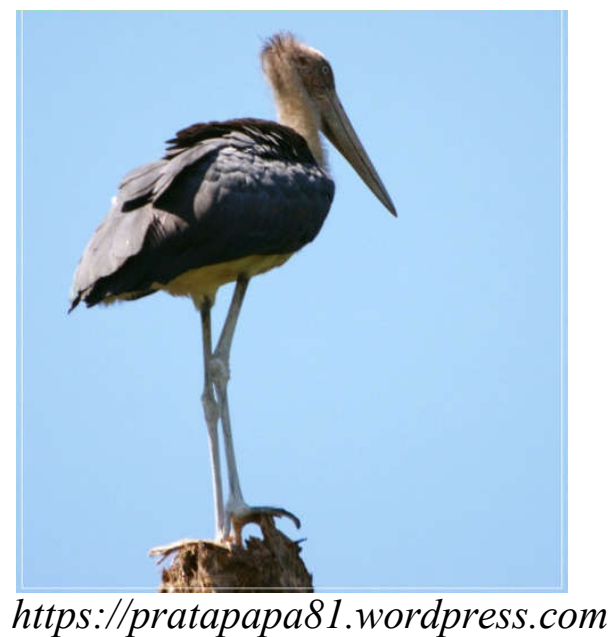

Perenjak Padi

( Prinia inornata blanfordi)
Blekok Sawah

(Ardeola speciosa)
Cekakak Sungai (Todirhamphus chloris)
Bangau Tongtong

(leptoptilos javanicus) 
Lampiran 3. Jenis Ikan yang terdapat di lokasi penelitian

1.

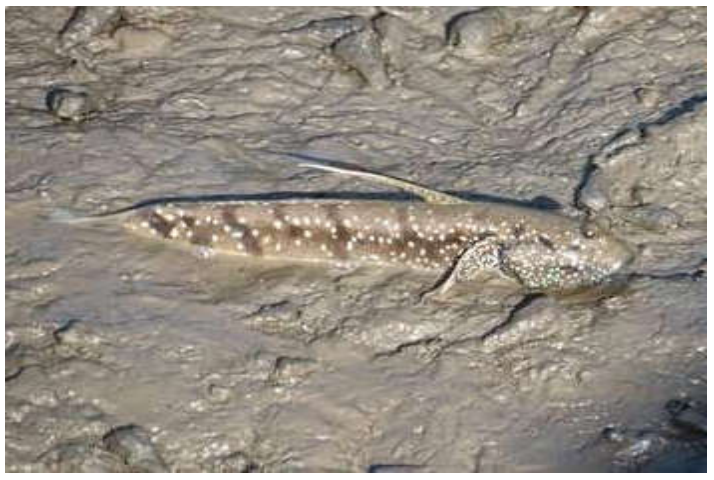

2.

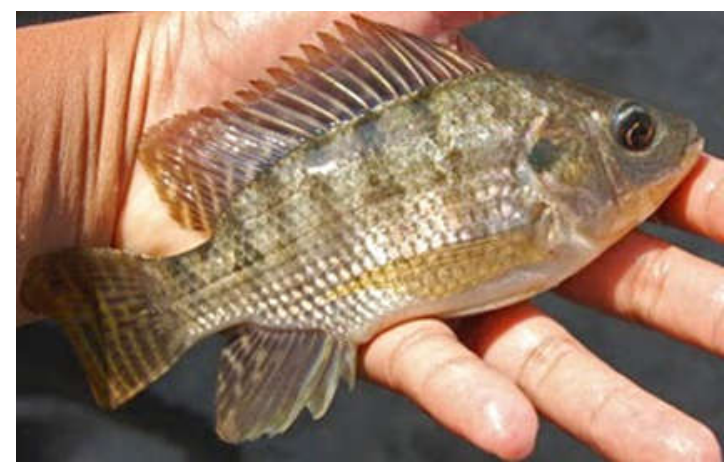

3.

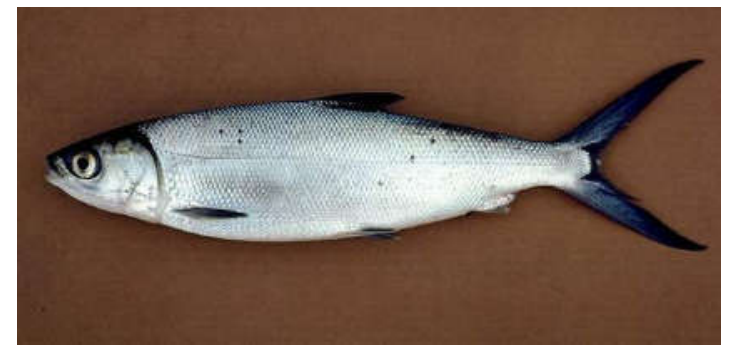

4.

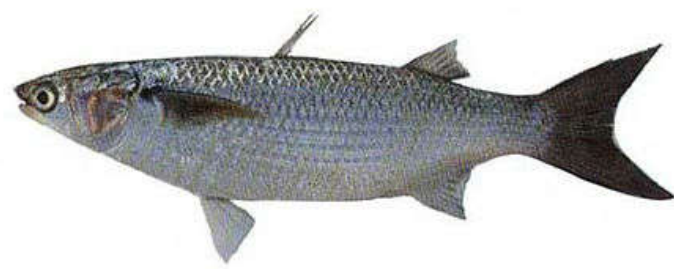

Ikan Glodok

(Periophthalmus sp)

\section{Mujair}

(Oreochromis Mossambicus)

Bandeng (Chanos chanos)

Balanak (Mugil sp) 
Lampiran 4. Jenis Crustacea yang terdapat di lokasi penelitian

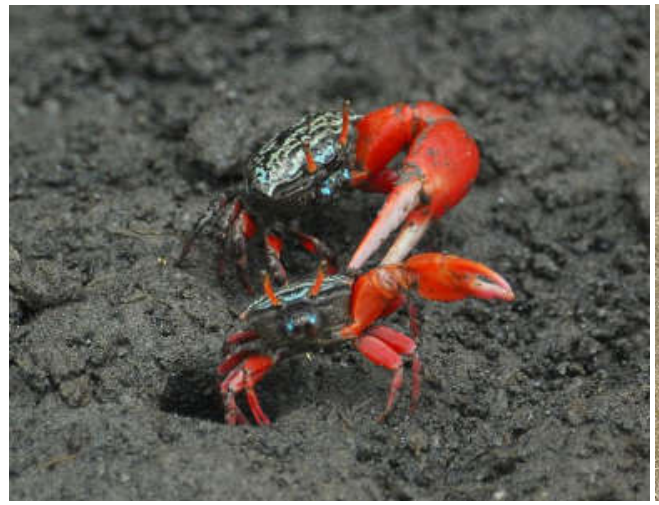

Uca crassipes.

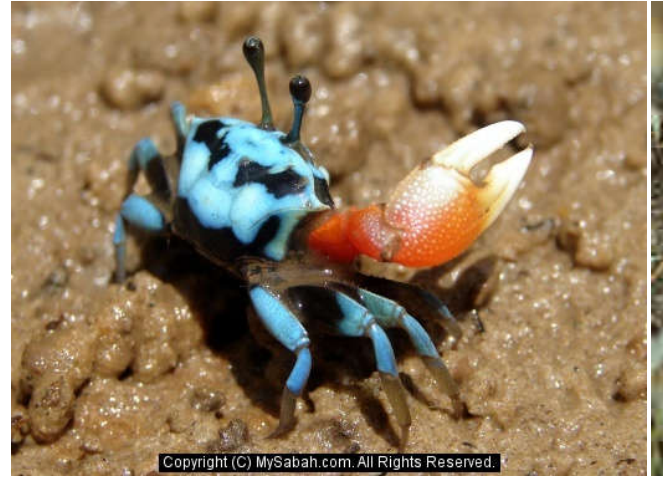

Uca tetragonon.

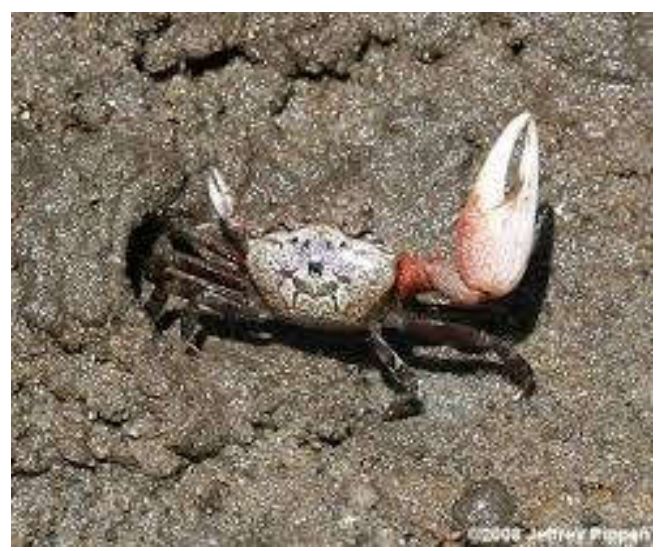

Uca sp.

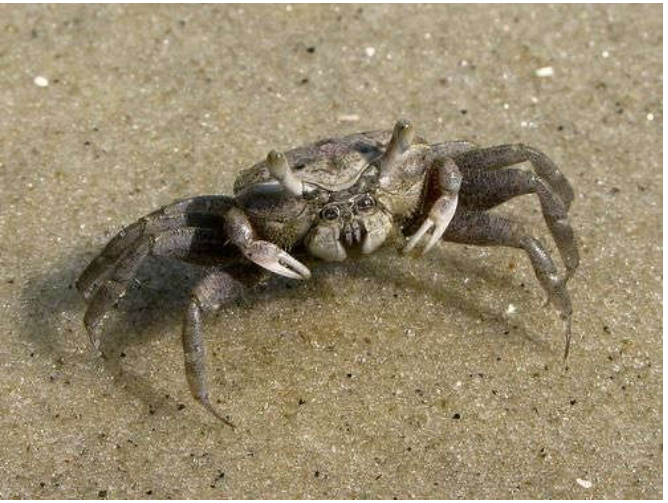

Sesarma spp.

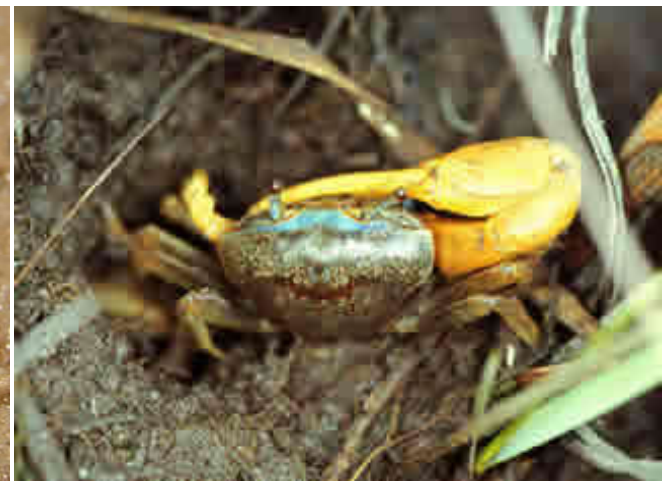

Uca spp. 
Lampiran 5. Dokumentasi Penelitian

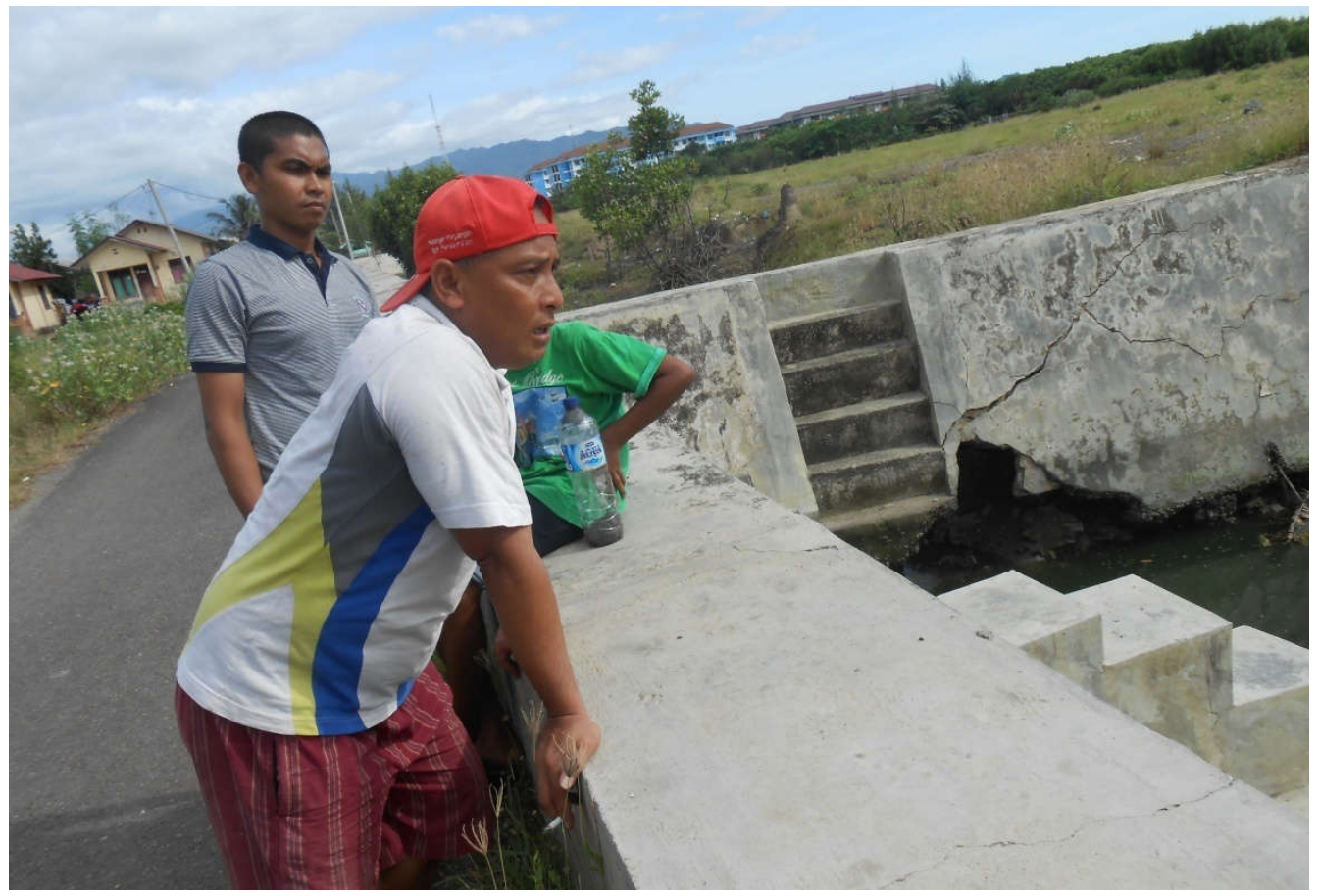

Gambar 1. Peneliti sedang diskusi dan wawancara dengan salah satu tokoh

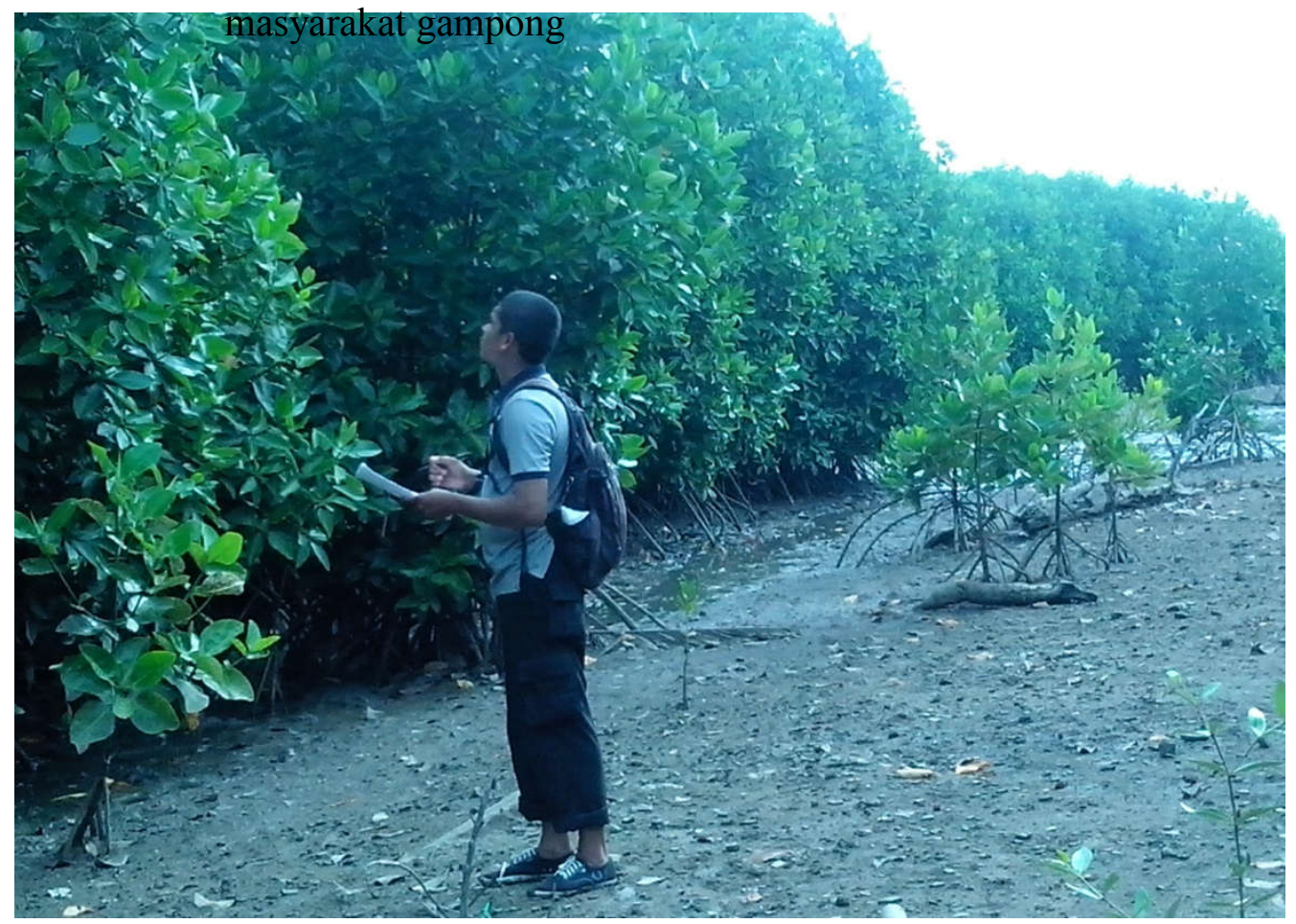

Gambar 2. Peneliti sedang mengidentifikasi jenis mangrove di lokasi Penelitian 


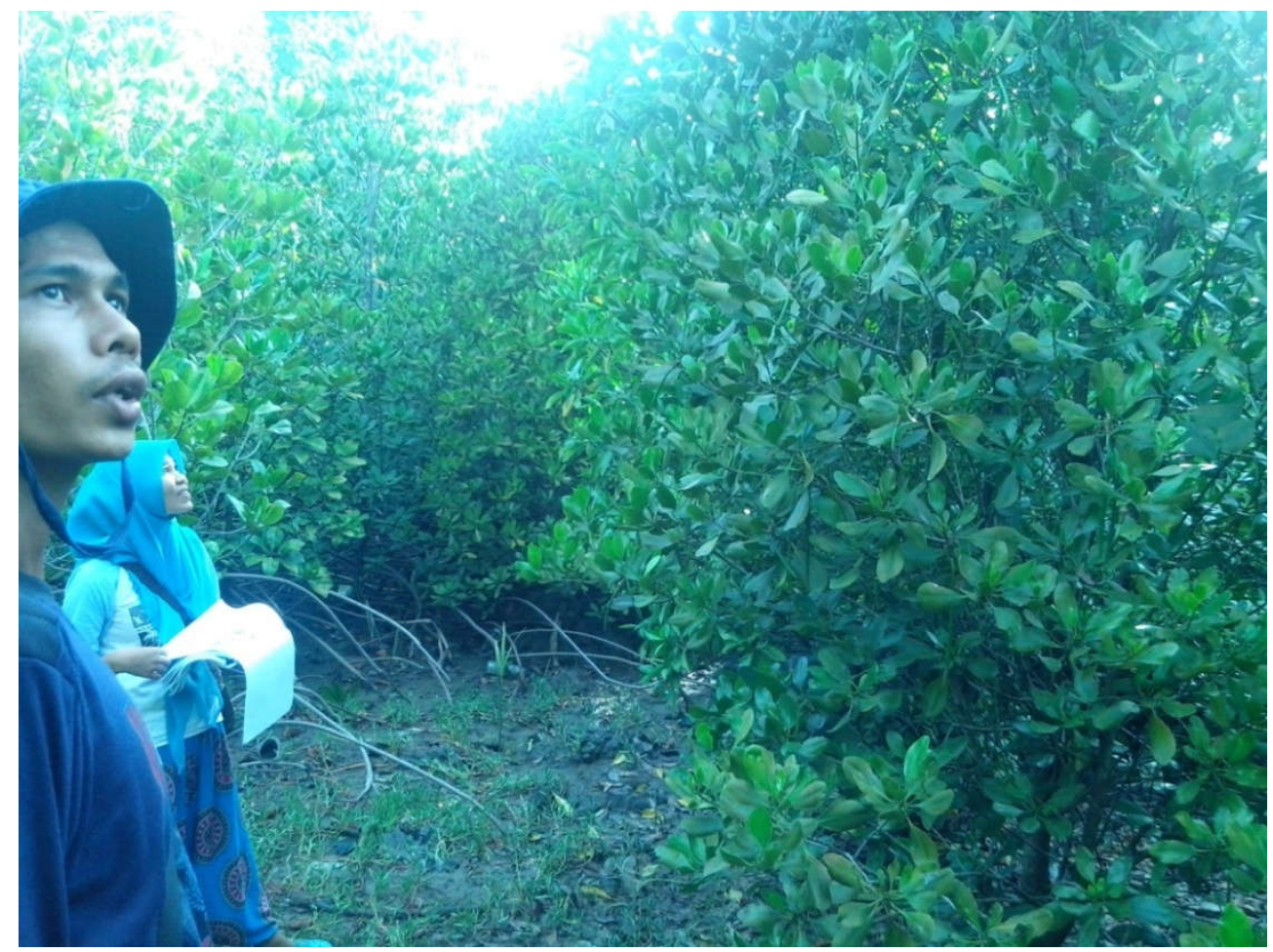

Gambar 3. Tim peneliti sedang mendiskusikan jenis mangrove di lokasi

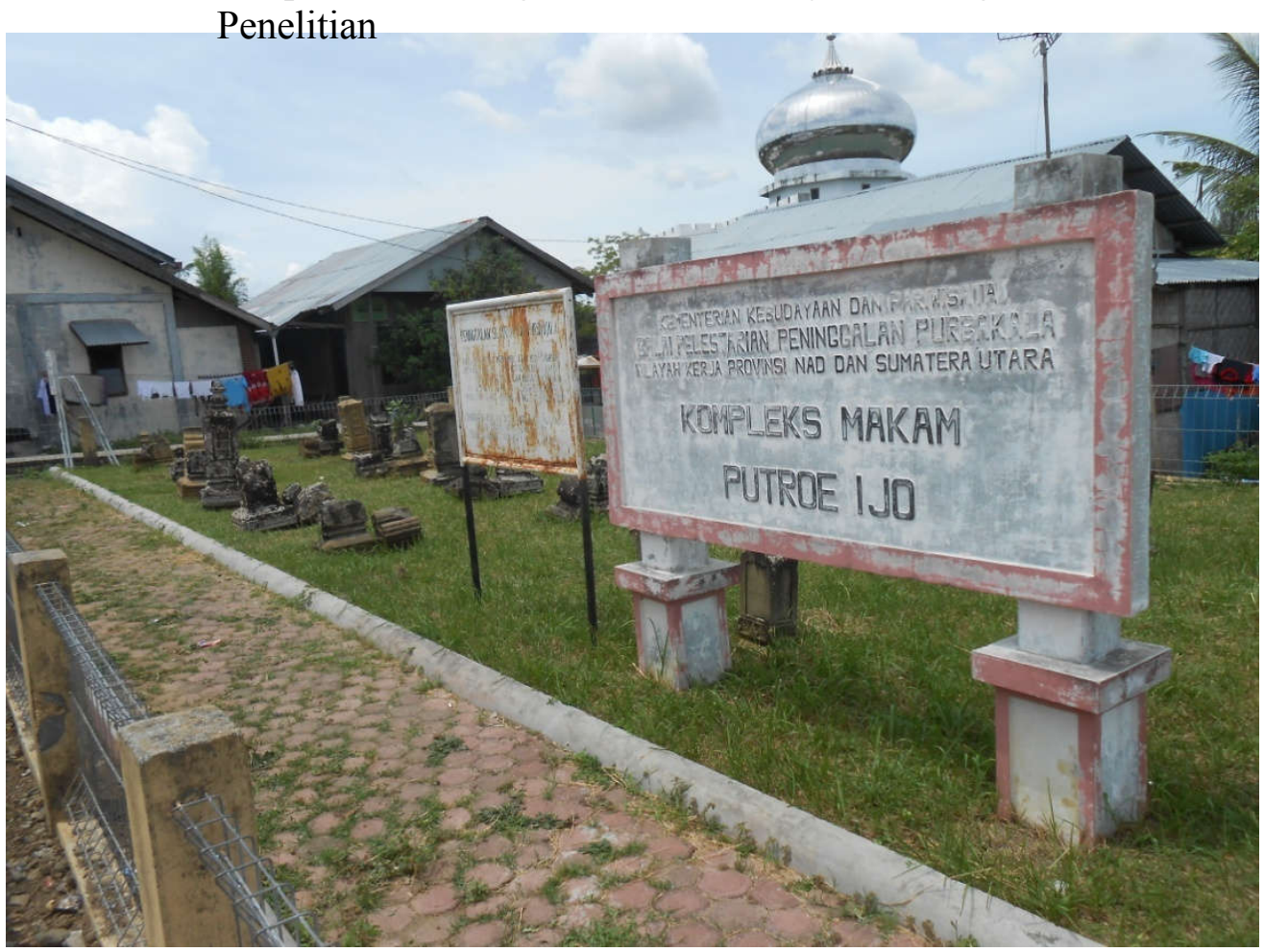

Gambar 4. Komplek Makam Kesultanan Aceh Putro Ijo yang terdapat dikawasan Hutan Mangrove 


\section{RIWAYAT HIDUP}

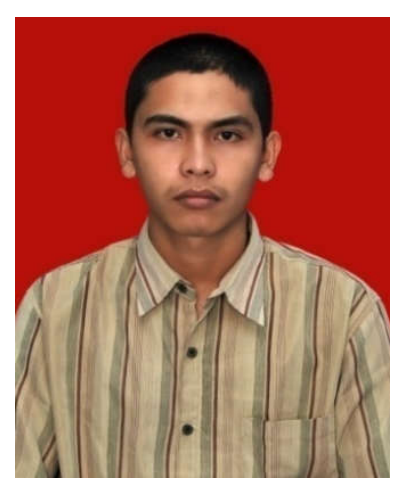

Syifa Saputra lahir pada tanggal 10 Februari 1987 di Cot

Baroh Kabupaten Bireuen, putra dari pasangan Drs. Muslim Ibrahim dan Nurdiah, A.Ma.Pd. Tanggal 05 April 2010 Menikah dengan Erlina Zakaria, S.Pd dan telah dikaruniai dua orang anak laki-laki yang bernama

M. Sulthan Almusawwa dan Ahmad Giza Albiruni. Pendidikan dasar ditempuh di Sekolah Dasar Negeri Cot Baroh tamat tahun 1999, Madrasah Tsanawiyah Negeri Model Gandapura tamat tahun 2002 dan Madrasah Aliyah Negeri Peusangan tamat tahun 2005. Kemudian pada tahun 2005 melanjutkan kuliah pada Fakultas Keguruan dan Ilmu Pendidikan Universitas Almuslim Bireuen dan tamat tahun 2010. Pada tahun 2011 mendapat kesempatan melanjutkan pendidikan pada Program Studi Magister Pendidikan Biologi Program Pascasarjana Universitas Syiah Kuala Banda Aceh. 